\title{
Soil and Phytosociological Characterisation of Grasslands in the Western Mediterranean
}

\author{
A. Cano-Ortiz1 , E. Bioindi², C. J. Pinto Gomes³ , S. Del Río González ${ }^{4}$, E. Cano ${ }^{5}$ \\ ${ }^{1}$ Department of Interra Sustainability, Resources Engineering and SL Spain Square, \\ Salamanca, Spain \\ ${ }^{2}$ Department of Environmental Sciences and Crop Production, Polytechnic University of Marche, \\ Ancona, Italy \\ ${ }^{3}$ Department of Landscape, Environment and Planning/Institute of Agricultural and Environmental Sciences \\ Mediterranean (ICAAM), University of Évora (Portugal), Rua Romão Ramalho, Portugal \\ ${ }^{4}$ Department of Biodiversity and Environmental Management (Department of Botany), Livestock Mountain \\ Institute (CSIC-ULE Joint Center), School of Biological and Environmental Sciences, University of León, \\ Vegazana Campus, León, Spain \\ ${ }^{5}$ Department of Animal Biology, Plant and Ecology, Botany, University of Jaén, Jaén, Spain \\ Email: ana@interra.es, e.biondi@univpm.it, cpgomes@uevora.pt, sriog@unileon.es, ecano@ujaen.es
}

Received 10 August 2014; revised 13 September 2014; accepted 18 October 2014

Copyright ( 2014 by authors and Scientific Research Publishing Inc.

This work is licensed under the Creative Commons Attribution International License (CC BY).

http://creativecommons.org/licenses/by/4.0/

(c) (i) Open Access

\section{Abstract}

A study was made of grasslands in olive groves with a high frequency of Hordeum leporinum Link, Chrysanthemum coronarium L., Malva neglecta Wallr., Aegilops geniculata Roth and Dasypyrum villosum (L.) Borbas, initially included in the alliance Hordeion leporini Br.-Bl. in Br.-Bl., Gajewski, Wraber \& Walas 1936 corr. O. Bolós 1962, and sub-alliance Malvenion neglectae Gutte 1966. The study was carried out in the western Mediterranean (Spain, Italy, Portugal and northern Morocco). The soil and phytosociological treatment of the samples contributes information for new plant communities. In the study of plant communities, the indices of degree of presence are adapted to those of Van der Maarel. The new alliance Securigero securidacae-Dasypyrion villosi is proposed for the sub-Mediterranean and Euro-Siberian territories, with the new communities Securigero securidacae-Dasypyretum villosi and Convolvulo elegantissimi-Aegilopetum geniculatae. This last community, due to its richness in Aegilops geniculata Roth, could be included in the alliance Taeniathero-Aegilopion geniculatae Rivas-Martínez \& Izco 1977; however, the soil and statistical analyses reveal that it should remain part of the alliance Securigero securidacae-Dasypyrion villosi. The soil and floristic study of Hordeion leporini and Malvenion neglectae allows us to describe the new sub-alliance Resedo albae-Chrysanthemenion coronarii, subordinated to Malvion neglectae (Gutte 1966) status novo. 


\section{Keywords}

\section{Soil, Grassland, Community, Association}

\section{Introduction}

The grassland communities studied are included by various authors [1]-[3], in the alliance Hordeion leporini, which comprises grasslands with a Mediterranean optimum, a sub-nitrophilous or nitrophilous character, and spring growth. This alliance extends throughout the sub-Mediterranean and central European territories. Although it has a Mediterranean optimum, this alliance can be found in Euro-Siberian (centre-European) areas such as the central Pyrenees (Spain) and the central Apennines (Italy), with a presence, in these latter territories and in Italian sub-Mediterranean environments, of species such as Dasypyrum villosum (L.) Borbas. These calcicolous species from southeast Europe are frequently found in Italy, and are absent in Spain and Portugal. The same occurs with Securigera securidaca (L.) Deg. et Dorfl., whose area of distribution is in southern Europe until southeast France; and Crepis sancta (L.) Babc., found in the samples taken in Italy, with a biogeographic area in the eastern Mediterranean region and in southeast Europe. All the communities of Dasyyirum villosum (L.) Borbas are grassland formations with dense coverage and considerable biomass which thrive in environments with a high quantity of organic matter [4]. This alliance includes some communities which, due to their structure, floristic composition and soil, should have been included in alliances other than Hordeion leporini. Alliance has been studied by other authors [5]-[10]. The soil parameters condition the presence of plant populations and communities, and this fact can be used to determine the soil nutrients according to the degree of presence and abundance of the species.

\section{Material and Methods}

\section{Study Area}

The territory in the study corresponds to the western Mediterranean (Spain, Italy, Portugal and northern Morocco). The samplings were taken in the spring of 2006. This study was initiated by [6] [7] in Spain and Portugal, and the Italian areas in Umbria and the Puglia region (Gargano) were inventoried by [5]. The communities in the sampling are distributed throughout the western Mediterranean, and the soil samples were taken in Andalusia (Spain), Alentejo (Portugal) and the regions of Umbria and Gargano (Italy) (Figure 1). Soil samples were taken of substrates with both acid and basic $\mathrm{pH}$, when the plant community presented a high abundance index of the dominant species.

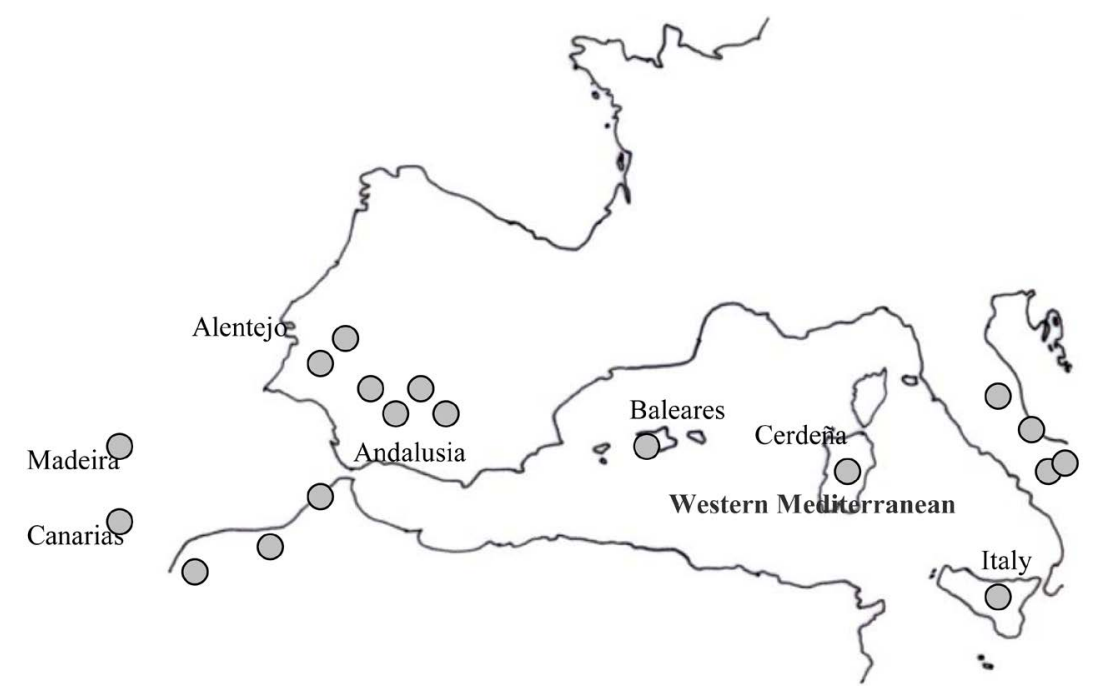

Figure 1. Localisation of soil sampling on the Iberian Peninsula and in Italy. 
The floras of [11] and [12], were used for the floristic and phytosociological study, and [13] for the phytosociological methodology. The soil study was done by taking 265 samples of each inventory of 14 plant communities, and the soil sample was obtained from the plant community where the dominant species has a high abundance-dominance index, and at the depth of the root system of each species. 16 soil parameters were analysed in the laboratory: exchangeable calcium (meq/100g), cation exchange capacity (meq/100g), carbonates (\%), assimilable phosphorus (p.p.m), exchangeable magnesium (meq/100g), oxidable organic matter (\%), total nitrogen (\%), pH 1/2.5, exchangeable potassium (meq/100g), pF 1/3 atm. (\%), pF 15 atm. (\%), electrical conductivity $1 / 5(\mathrm{mmhos} / \mathrm{cm})$, clayey texture (\%), silty texture (\%), sandy texture (\%), and exchangeable sodium (meq/100g).

In order to differentiate the communities of Hordeion leporini in the western Mediterranean, a synthetic Excel chart was drawn up based on the 74 association tables which include 847 inventories (Table 1), and comprise 740 rows (species) $\times 74$ columns (association tables). The degrees of presence used were according to [13], which range from $\mathrm{I}$ to $\mathrm{V}$ with the following \% equivalence: $\mathrm{V}$ implies that the degree of presence of the species in the samples taken ranges between $80 \%$ and $100 \%$; IV from $60 \%$ to $80 \%$, III from $40 \%-60 \%$, II from $20 \%$ $40 \%$ and $\mathrm{I}<20 \%$. In our case we applied the following formula in order to obtain the index value (degree of presence): $\mathrm{Ip}=\mathrm{n}$. V/T, where Ip = index of presence; $\mathrm{n}=$ number of inventories in the table of the community in which the species is included; $\mathrm{V}=$ maximum presence value (the species is included in all the inventories in the community table); $\mathrm{T}=$ total number of inventories in the table. Based on this criterion we used the following Ip values; an Ip value of $>4.5$ is assigned a presence value of V; Ip = $3.5-4.5$ a value of IV; Ip = 2.5 - 3.5 a value of III; Ip = $1.5-2.5$ : II; and finally Ip $<1.5$ is assigned a value of I. Once the synthetic table of the 74 community tables was drawn up, we adapted these indices to the [42]. I = 3; II = 4; III = 5; IV =6; V = 7 .

A cluster was applied to the Excel chart of 740 rows (species) $\times 74$ columns (association tables) with the Jaccard distance, in order to establish the degree of similarity/dissimilarity between the association tables. It was similarly applied to the synthetic species tables for Italy, the Iberian Peninsula and northern Morocco (Spain, Portugal, northern Morocco), which comprise 444 rows $\times 26$ columns and 528 rows $\times 47$ columns respectively, to determine the distance existing between the different associations present in each territory. The previous analysis was corroborated with DECORANA ordination and RA analysis to establish the difference between the groups.

A table of averages was drawn up using the 265 soil samples and a PCA was applied to determine which soil factors condition the presence of the plant community.

In order to differentiate the Italian communities rich in Dasypyrum villosum (L.) Borbas, a statistical treatment of conglomerates was performed. This was done by drawing up several Excel charts; one with the 45 phytosociological field samples plus 63 inventories of proximate associations due to their richness in Dasypyrum villosum (L.) Borbas (281 rows $\times 108$ columns), to which was subsequently applied a cluster analysis using the Euclidean distance.

In order to determine in which alliance to include the Italian community of Convolvulus elegatissimus Miller and Aegilops geniculata Roth, two Excel charts were made with the 45 soil and community samples from Italy plus 41 from the Iberian Peninsula which were very similar to the Italian samples in terms of structure and floristic composition, and comprising 16 soil parameters $\times 86$ columns (samples), with subsequent application of cluster and PCA. The 41 Iberian samples belonged to the associations Trifolio cherleri-Taeniatheretum capitismedusae Rivas-Martínez \& Izco 1977 (TT) and Plantago bellardii-Aegilopetum geniculatae Cano-Ortiz, Pinto Gomes \& Cano 2010 (PA), described for Portugal [8].

The data used were included in a synthetic table of presences with 740 rows (species) $\times 74$ association tables, and in a soil table of 265 samples $\times 16$ soil parameters.

\section{Results and Discussion}

A statistical treatment was performed on 12 of the 16 soil parameters analysed in each one of the 265 samples, as two of the soil parameters obtained did not appear to be relevant (Table 2). This allows us to confirm that $\mathrm{MOO}, \mathrm{Nt}$ and $\mathrm{CIC}$ are the factors which have the greatest influence in communities $\mathrm{AB}, \mathrm{SD}$ and CA present in Italy (Ge1) (Figure 2 and Figure 3), with a lower influence of Pa, Mgc and Kc; conversely in the group of grassland communities present on the Iberian peninsula, TT, LR, ArH, BH, ArChr, PA and ArP, the most relevant factor is texture $(\mathrm{Ge} 2)$. The edaphic study of 14 communities served to establish the abundance of the do- 
Table 1. Associations studied in the western Mediterranean.

\begin{tabular}{|c|c|c|}
\hline Ass & Sintaxon & N. inv. \\
\hline 1 & Bromo scoparii-Hordeetum leporinii Rivas-Martínez 1978 [2] & 17 \\
\hline 2 & Bromo scoparii-Hordeetum leporinii subas. sisymbrietosum officinalis Rivas-Martínez 1978 [2] & 10 \\
\hline 3 & Bromo scoparii-Hordeetum leporinii subas. diplotaxietosum catholicae Rivas-Martínez 1978 [2] & 8 \\
\hline 4 & Papaveri rhoeadi-Diplotaxietum virgatae Rivas-Martínez 1978 [2] & 11 \\
\hline 5 & Papaveri rhoeadi-Diplotaxietum virgatae Rivas-Martínez 1978 var con Sisymbrium runcinatum [2] & 5 \\
\hline 6 & Papaveri rhoeadi-Diplotaxietum virgatae Rivas-Martínez 1978 subas. erucetosum vesicariae Rivas-Martínez 1978 [2] & 2 \\
\hline 7 & Papaveri rhoeadi-Diplotaxietum virgatae Rivas-Martínez 1978 subas. sisymbrietosum contorti Rivas-Martínez 1978 [2] & 2 \\
\hline 8 & Anacyclo radiati-Hordeetum leporini O. Bolòs \& Rivas-Martínez in Rivas-Martínez 1978 [2] & 4 \\
\hline 9 & $\begin{array}{l}\text { Anacyclo radiati-Hordeetum lepronii O. Bolòs \& Rivas-Martínez in Rivas-Martínez } 1978 \text { subas. } \\
\text { chrysanthemetosum coronarii Rivas-Martínez } 1978 \text { [2] }\end{array}$ & 5 \\
\hline 10 & $\begin{array}{l}\text { Anacyclo radiati-Hordeetum leporinii O. Bolòs \& Rivas-Martínez in Rivas-Martínez } 1978 \text { subas. } \\
\text { arthocethosum calendulae Rivas-Martínez } 1978 \text { [2] }\end{array}$ & 4 \\
\hline 11 & Resedo albae-Chrysanthemetum coronarii O. Bolòs \& Molinier 1958 [Own inventories] & 20 \\
\hline 12 & Anacyclo radiati-Papaveretum rhoeadis Cano-Ortiz et al. 2009 [6] & 20 \\
\hline 13 & Anacyclo radiati-Chrysanthemetum coronarii Rivas-Martínez 1978 \& Cano-Ortiz et al. 2009 [6] & 20 \\
\hline 14 & Anacyclo radiati-Hordeetum leporinii Rivas-Martínez 1978 [Own inventories] & 20 \\
\hline 15 & Anacyclo clavati-Hordeetum leporinii Cano-Ortiz et al. 2009 [7] & 20 \\
\hline 16 & Bromo scoparii-Hordeetum leporinii Rivas-Martínez 1978 [7] & 20 \\
\hline 17 & Hordeetum leporini Br. Bl. 1936 [15] & 7 \\
\hline 18 & Carduo tenuiflori-Hordeetum leporini Br.-Bl. 1931 [3] & 4 \\
\hline 19 & Bromo-Hirschfeldietum incanae Lohmeyer 1975 [16] & 7 \\
\hline 20 & $\begin{array}{c}\text { Sisymbrio officinalis-Hordeetum Marini Br.-Bl. } 1967 \text { subas. hordeetosum murini y subas. anacycletosum clavati } \\
\text { Fernández-González \& Sardinero in Sardinero 2004. Bromo scoparii-Hordeetum leporini Rivas-Martínez } 1978 \text { subas. } \\
\text { sisymbrietosum officinalis Rivas-Martínez } 1978 \text { [17] }\end{array}$ & 13 \\
\hline 21 & Resedo albae-Chrysanthemetum coronarii O. Bolòs \& Molinier 1958 [18] & 8 \\
\hline 22 & Iondrabo auriculatae-Erucetum vesicariae Rivas-Martínez 1978 [18] & 4 \\
\hline 23 & Iondrabo auriculatae-Erucetum vesicariae Rivas-Martínez 1978 [2] & 12 \\
\hline 24 & Iondrabo auriculatae-Erucetum vesicariae Rivas-Martínez 1978 subas. diplotaxietosum virgatae Rivas-Martínez 1978 [2] & 4 \\
\hline 25 & Rapistro rugosi-Sisymbrietum crassifolii Rivas-Martínez 1978 [2] & 13 \\
\hline 26 & Hordeo leporini-Glossoppapetum macroti Peinado, Martínez-Parras \& Bartolomé 1986 [19] & 10 \\
\hline 27 & Papaveri rhoeadi-Diplotaxietum virgatae Rivas-Martínez 1978 [5] & 20 \\
\hline 28 & Co. Linaria spartea et Raphanum raphanistrum [9] & 24 \\
\hline 29 & Raphano raphanistri-Diplotaxietum catholicae Vicente Orellana \& Galán 2008 [20] & 9 \\
\hline 30 & Asphodelo fistulosi-Hordeetum leporini A. \& O. Bolòs in O. Bolòs 1956 [21] & 3 \\
\hline 31 & Resedo albae-Chrysanthemetum coronarii O. Bolòs \& Molinier 1958 [22] & 5 \\
\hline 32 & Resedo albae-Chrysanthemetum coronarii O. Bolòs \& Molinier 1958 [23] & 8 \\
\hline 33 & Anacyclo radiati-Hordeetum leporini O. Bolòs \& Rivas-Martínez in Rivas-Martínez 1978 [24] & 5 \\
\hline 34 & Anacyclo radiati-Hordeetum leporini O. Bolòs \& Rivas-Martínez in Rivas-Martínez 1978 [25] & 4 \\
\hline 35 & $\begin{array}{l}\text { Aveno lusitanicae-Hordeetum leporini Espirito Santo, J. C. Costa, Jardin \& Sequeira } 2004 \text { subas. } \\
\text { chrysanthemetosum coronari Capelo et al. } 2004 \text { [10] }\end{array}$ & 9 \\
\hline 36 & Bromo madritensis-Galactitetum tomentosae O. Bolòs, Molinier \& P. Monserrat 1970 [26] & 5 \\
\hline
\end{tabular}




\section{Continued}

Eruco longirostris-Diplotaxietum erucoidis Rigual 1972 corr. Alcaraz 1984 [21] 4

Asphodelo fistulosi-Hordeetum leporini A. \& O. Bolòs in O. Bolòs 1956 subas. spergularietosum Esteve 1972 [27] 14

.Asphodelo fistulosi-Hordeetum leporini A. \& O. Bolòs in O. Bolòs 1956 [28]

Anacyclo radiati-Hordeetum leporini O. Bolòs \& Rivas-Martínez in Rivas-Martínez 1978 subas. typicum; subas. chrysanthemetosum coronarii Rivas-Martínez 1978 y subas. notobasetosum syriacae Galán, Deil, V. Orellana \& Müller 2004 [29]

Anacyclo radiati-Hordeetum leporini O. Bolòs \& Rivas-Martínez in Rivas-Martínez 1978 subas. notobasetosum syriacae Galán, Deil, V. Orellana \& Müller 2004 [29]

Hordeo leporini-Glossoppapetum macroti Peinado, Martínez-Parras \& Bartolomé 1986 [29]

Sisymbrio irionis-Sinapietum mairei P. Prieto, Espinosa \& S. Fernández 1973 corr. Rivas-Martínez et al. 2002 [30]

Schismo calycini-Malvetum trifidae Br.-Bl., Font Quer, G. Br.-Bl., Frey, Jansen \& Moor 1936 [14]

Euphorbio terracinae-Anacycletum coronati Reyes, Wildpret \& León 2001 [31]

Bromo-Hirschfeldietum incanae Lohmeyer 1975 [31]

Aveno barbatae-Brometum diandri Baldoni \& Biondi 1993 [Own inventories]

Dasypyro-Aegilopetum triuncialis Brullo, Scelsi \& Spanpinato 2001 [32]

Malvo parviflorae-Chrysanthemetum coronarii Ferro 1980 [1]

Hypochoerido-Plantaginetum serrariae Brullo 1983 [1]

Hordeo-Centauretum macracanthae Brullo 1983 [1] 


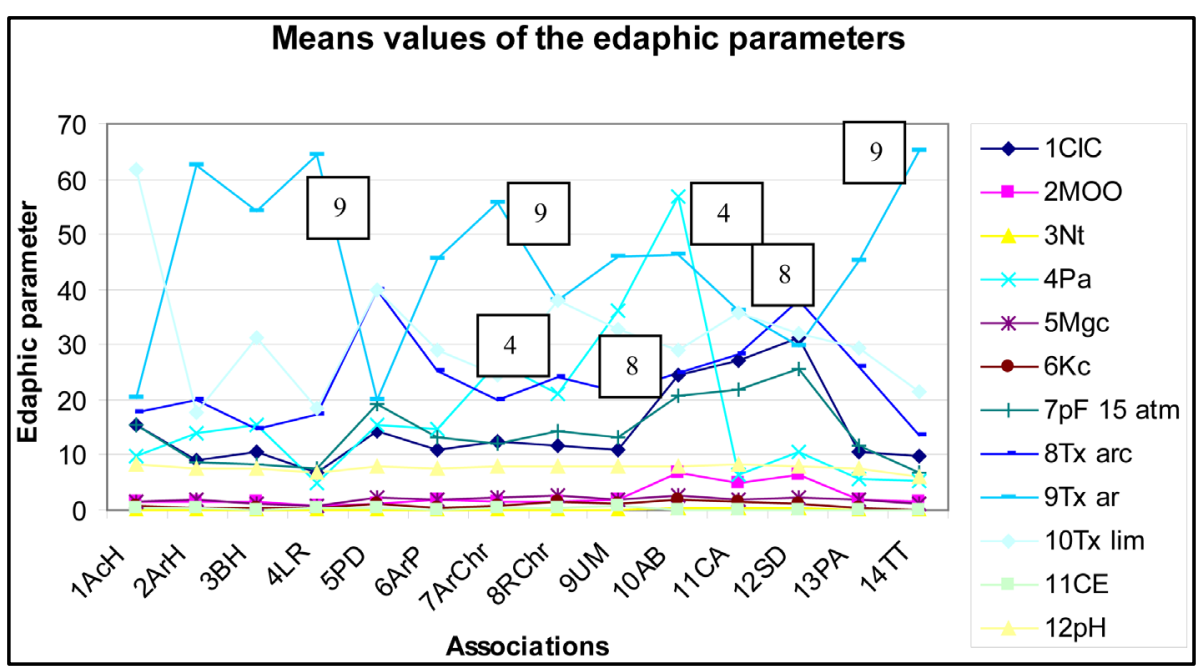

Figure 2. Soil parameters with the greatest influence on plant communities.

PCA Plot - Correlation - VALUES EDAPHIC1

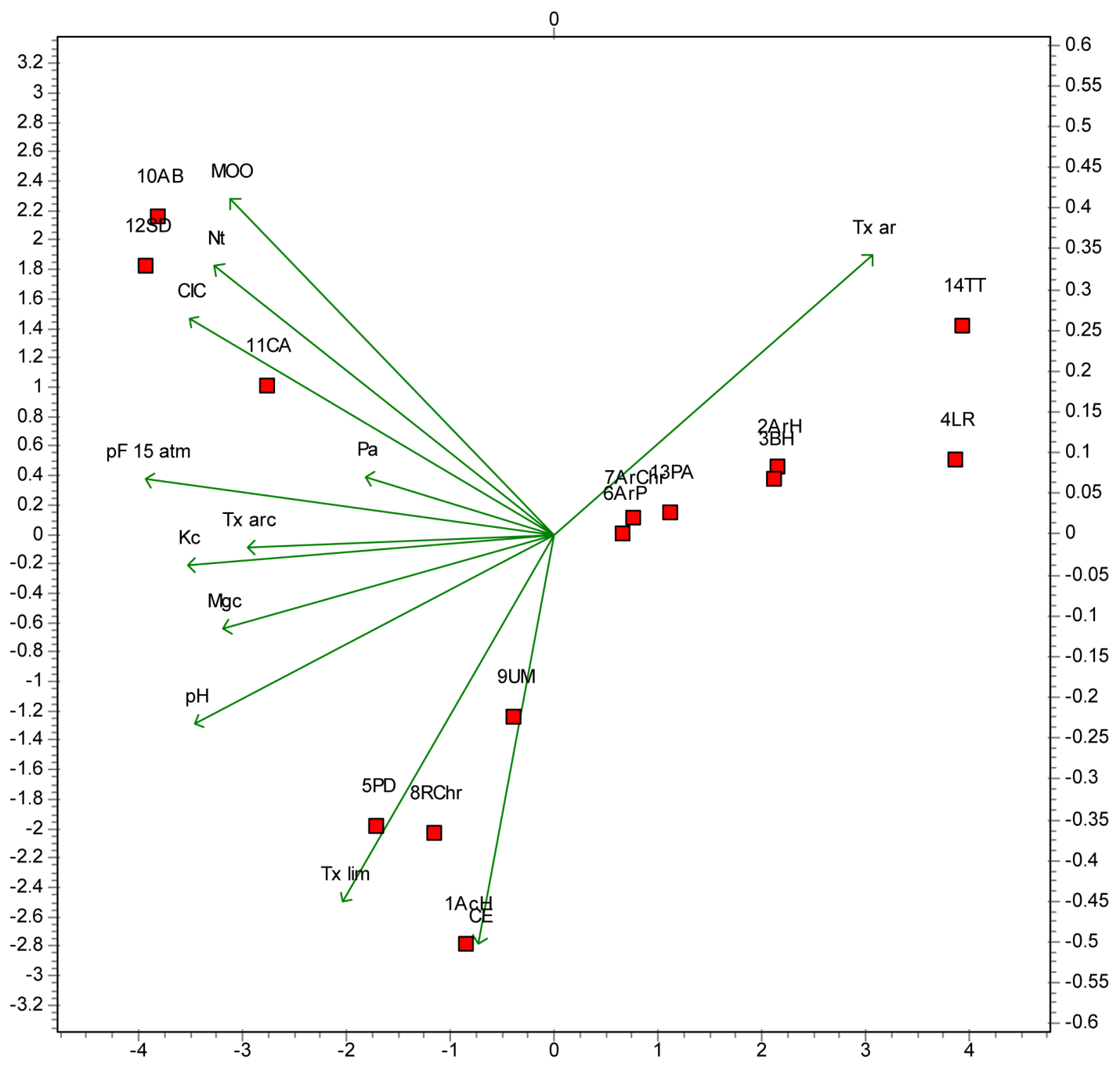

Figure 3. Soil parameters with the greatest influence on plant communities. PCA analysis. 
Table 2. Average values of the soil parameters studied.

\begin{tabular}{ccccccccccccccc}
\hline & $1 \mathrm{AcH}$ & $2 \mathrm{ArH}$ & 3BH & 4LR & 5PD & 6ArP & 7ArChr & 8RChr & 9UM & 10AB & 11CA & 12SD & 13PA & 14TT \\
\hline CIC & 15.365 & 9.131 & 10.544 & 6.661 & 14.304 & 10.869 & 12.328 & 11.68 & 10.889 & 24.478 & 26.99 & 31.237 & 10.54 & 9.63 \\
MOO & 1.541 & 1.56 & 1.667 & 0.75 & 1.02 & 1.803 & 1.622 & 1.574 & 1.904 & 6.679 & 5.002 & 6.426 & 1.8 & 1.458 \\
Nt & 0.115 & 0.102 & 0.133 & 0.064 & 0.09 & 0.14 & 0.105 & 0.129 & 0.179 & 0.309 & 0.216 & 0.283 & 0.136 & 0.084 \\
Pa & 9.789 & 13.957 & 15.4 & 4.824 & 15.35 & 14.722 & 26.9 & 20.95 & 36.19 & 56.788 & 6.582 & 10.689 & 5.605 & 5.111 \\
Mgc & 1.683 & 1.856 & 1.068 & 0.835 & 2.351 & 1.864 & 2.131 & 2.716 & 1.698 & 2.51 & 1.931 & 2.186 & 1.713 & 1.097 \\
Kc & 0.79 & 0.256 & 0.375 & 0.259 & 1.002 & 0.412 & 0.698 & 1.476 & 1.266 & 1.804 & 1.515 & 1.079 & 0.206 & 0.156 \\
pF 15 atm & 15.322 & 8.613 & 8.203 & 7.366 & 19.117 & 13.001 & 11.975 & 14.24 & 13.197 & 20.783 & 21.82 & 25.704 & 11.82 & 6.673 \\
Tx arc & 17.758 & 19.78 & 14.503 & 17.28 & 40.015 & 25.394 & 19.763 & 24.24 & 21.293 & 24.894 & 28.13 & 38.122 & 25.83 & 13.59 \\
Tx ar & 20.448 & 62.411 & 54.254 & 64.238 & 19.986 & 45.694 & 55.826 & 37.85 & 46.001 & 46.244 & 35.95 & 29.844 & 44.98 & 64.93 \\
Tx lim & 61.794 & 17.803 & 31.245 & 18.51 & 40 & 28.906 & 24.413 & 37.94 & 32.712 & 28.863 & 35.93 & 32.033 & 29.2 & 21.49 \\
CE & 0.355 & 0.209 & 0.122 & 0.211 & 0.286 & 0.162 & 0.193 & 0.491 & 0.565 & 0.17 & 0.104 & 0.118 & 0.105 & 0.049 \\
pH & 8.275 & 7.43 & 7.475 & 6.616 & 8.085 & 7.633 & 7.77 & 7.943 & 7.776 & 8.044 & 8.225 & 8.021 & 7.581 & 6.13
\end{tabular}

$\mathrm{CIC}=$ cation exchange capacity in meq/100g; $\mathrm{MOO}=$ oxidable organic matter in \%; Nt = total nitrogen in \%; Pa = assimilable phosphorus in ppm; Mgc = exchangeable magnesium in meq/100g; Kc = exchangeable potassium in meq/100g; pF 15 atm = pressure at 15 atm (water retention capacity) in \%; Tx arc = clayey texture in \%; Tx ar = sandy texture in \%; Tx lim = silty texture in \%; EC = conductivity mmhos/cm; pH. 1AcH.-Anacyclo clavati-Hordeetum leporini Cano-Ortiz et al. 2009. 2ArH.-Anacyclo radiati-Hordeetum leporinii O. Bolòs \& Rivas-Martínez in Rivas-Martínez 1978. 3BH.-Bromo scoparii-Hordeetum leporinii Rivas Martínez 1978. 4LR.-Co. Linaria spartea et Raphanum raphanistrum. 5PD.-Papaveri rhoeadis-Diplotaxietum virgatae Rivas Martínez 1978. 6ArP.-Anacyclo radiati-Papaveretum rhoeadis Cano-Ortiz et al. 2009. 7ArChr.-Anacyclo radiati-Chrysanthemetum coronarii (Rivas-Martínez 1978) CanoOrtiz et al. 2009. 8RChr.-Resedo albae-Chrysanthemetum coronarii O. Bolòs \& Molinier 1958. 9UM.-Urtico urentis-Malvetum neglectae (Knapp) Lohmeyer in Tüxen 1950. 10AB.-Aveno barbatae-Brometum diandri Baldoni \& Biondi 1993. 11CA.-Convolvulo elegantissimi-Aegilopetum geniculatae. 12SD.Securigero securidacae-Dasypyretum villosii. 13PA.-Plantagini bellardii-Aegilopetum geniculatae Cano-Ortiz, Pinto \& Cano 2010. 14TT.-Trifolio cherleriTaeniatheretum capitis-medusae Rivas-Martínez \& Izco 1977.

minant species of each association, and will be essential for future studies on soil indicators. This work refers mainly to the description of new syntaxa.

In the PCA analysis (Figure 4) we have included 14 soil parameters and 86 samples, 45 of which correspond to the communities $\mathrm{AB}, \mathrm{CA}$ and $\mathrm{SD}$, plus 41 to the Iberian communities PA and TT. In the PCA correlation analysis, the Italian grasslands $\mathrm{AB}, \mathrm{CA}$ and $\mathrm{SD}$ are grouped on one side and the Iberian grasslands are grouped on the other, thus highlighting the fact that although the CA community in Italy has a structure close to the communities of Taeniatherum caput-medusae (L.) Nevski and Aegilops geniculata Roth, its floristic composition and the substrate on which this community grows allows us to include it with the rest of the Italian communities rich in Dasypyrum villosum (L.) Borbas.

The first cluster analysis (Figure 5) performed to establish the similarity/dissimilarity between the different associations present in the western Mediterranean revealed two groups of associations very distant from each other: group G1 from 1 - 50 and group G2 from 11 to 47, with a distance of $100 \%$ between them. Of the 74 community tables, $42(57.5 \%)$ have a distance of $75 \%$, which highlights the substantial differences between the communities in the study.

Taking into consideration the dominant species in each community table, it can be seen in the cluster that the tables rich in Hordeum leporinum Link are distant from those which have a predominance of Chrysanthemum coronarium L. or Dasypyrum villosum (L.) Borbas. The tables rich in Hordeum leporinum Link are distributed with 15 in group G1 and 5 in G2; whereas all the tables with high indices of Chrysanthemum coronarium L. are grouped in G2. When the tables correspond to the same association-for example, 21 and 32-they have a high degree of similarity, with $94.12 \%$. Both the communities with a high frequency of Chrysanthemum coronarium L. and those of Dasypyrum villosum (L.) Borbas have differences of over $75 \%$ with regard to those in which Hordeum leporinum Link is the dominant species. The floristic study shows clear differences between the 47 association tables from Spain, Portugal and northern Morocco, with 21 communities of 516 species, and the 27 tables from Italy with 22 communities of 448 species; this highlights a different floristic diversity in grasslands in the Iberian olive groves compared to Italian grasslands. 
PCA Plot - Correlation - ClusterCA-TT-PA-SD-AB

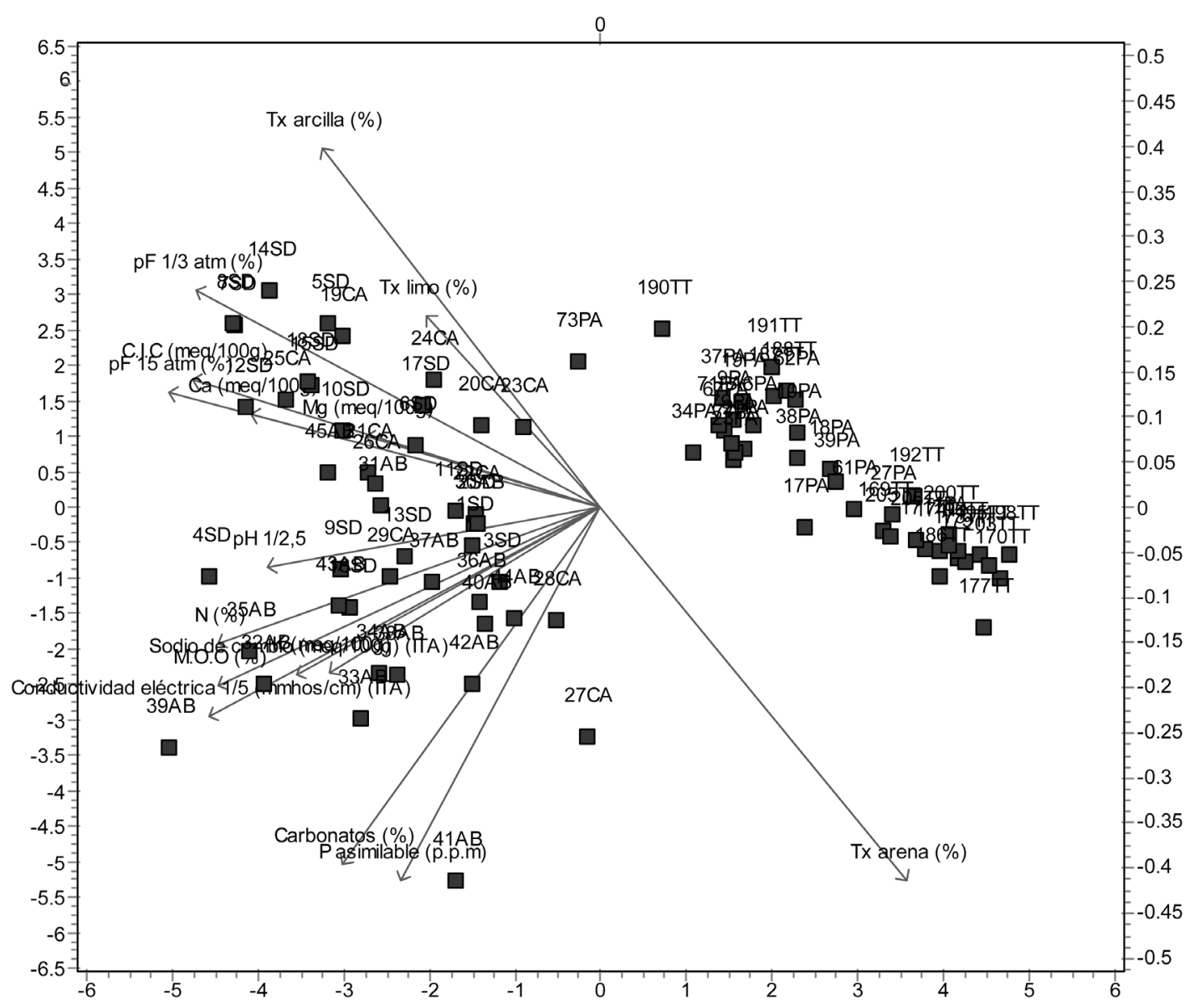

Figure 4. Soil correlation analysis for the associations in Italy (CA, SD, AB), Spain (TT) and Portugal (PA).

In view of the substantial soil differences in terms of organic matter, nitrogen, phosphorus and potassium, in addition to the floristic and structural differences, we propose for the centre-east of the Mediterranean territories the alliance Securigero securidacae-Dasypyrion villosi nova, an alliance with a Euro-Siberian and sub-Mediterranean optimum characterised by Centaurea napifolia L., Crepis sancta (L.) Babc., Dasypyrum villosum (L.) Borbas, Bromus erectus Huds., Cerastium ligusticum Viv., Picris hieracioides L., Vulpia ligustica (All.) Link. In this alliance we include the grassland communities from Euro-Siberian and sub-Mediterranean environments which present a high frequency of Dasypyrum villosum (L.) P. Candargy, which have until now been included in the alliance Hordeion leporini Br.-Bl. In Br.-Bl., Gajewski, Wraber \& Walas 1936 corr. O. Bolòs 1962. We adopt as type of the new alliance the association Bromo rigidi-Dasypiretum villosi Pignatti 1953.

The communities dominated by Chrysanthemum coronarium L. or by Hordeum leporinum Link have significant structural, soil and floristic differences. At the soil level the communities of Chrysanthemum coronarium L. present soil parameter values of MO, Nt, P, K, and Mg which are closer to those of the communities of Malvenion neglectae Gutte 1966 than to those of Hordeion leporinii (Table 2); the frequent presence of species of Malvenion neglectae in the communities of Chrysanthemum coronarium L. and a vegetation structure of Malvenion neglectae [43], is sufficient reason to propose the new sub-alliance Resedo albae-Chrysanthemenion coronarii all nova which we subordinate to Malvion neglectae (Gutte 1966) status novo.

Separately we applied a Jaccard distance and RA ordination cluster analysis to the westernmost communities (Spain, Portugal and northern Morocco) (association tables 1 - 47) and to the Italian communities (48 - 74) in Table 1. Group EP1 appears in the first case, and includes the associations rich in Chrysanthemum coronarium L. and a group of associations EP2 dominated by Hordeum leporinum Link (Figure 7). In the RA analysis, all the tables of the different associations form a compact group C (tables 1 - 44) with the exception of tables 45 , 46 


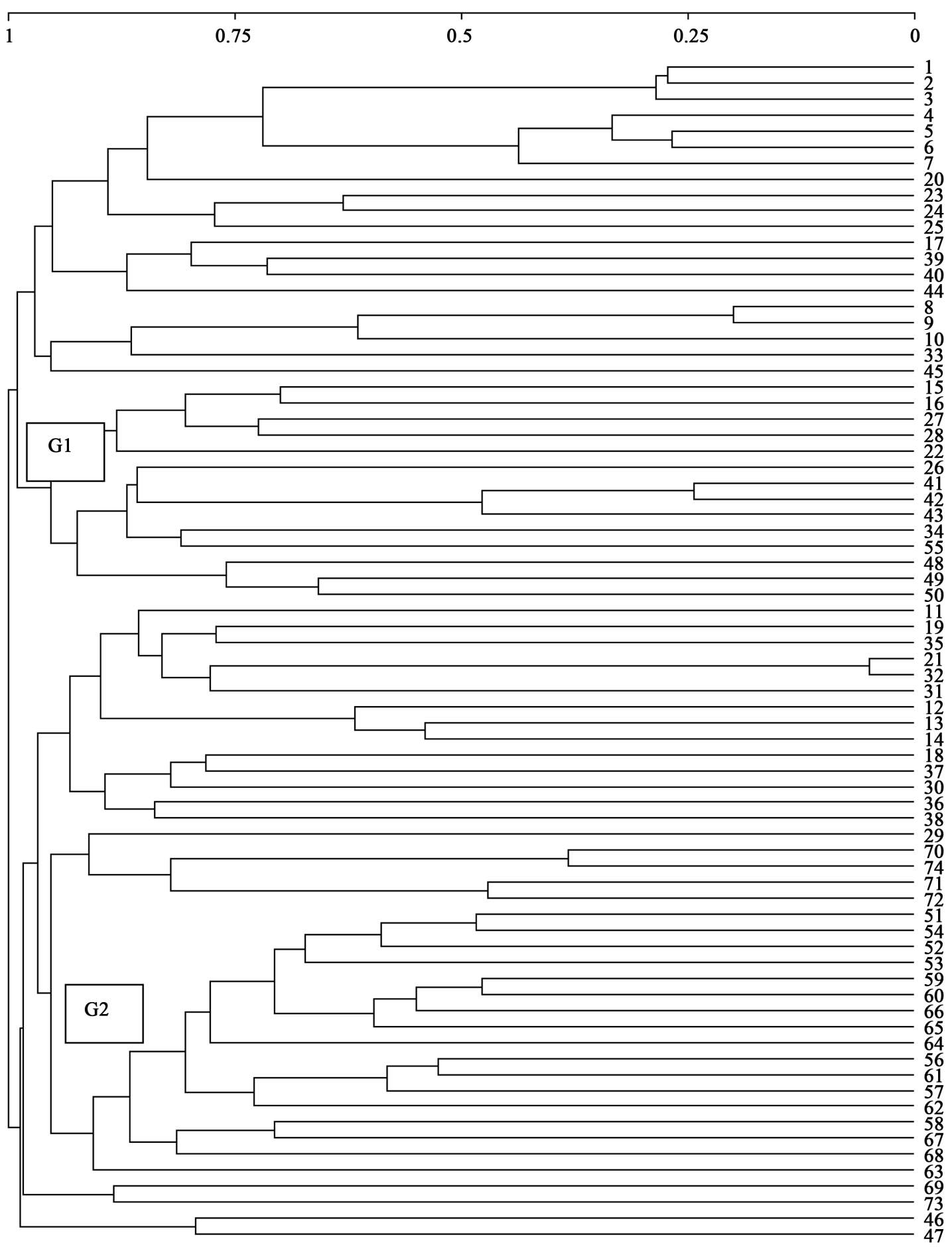

Figure 5. Clustering obtained from 740 rows (plants) $\times 74$ association tables using Jaccard distance.

and 47 corresponding to the associations (45) Schismo calycini-Malvetum trifidae Br.-Bl., Font Quer, G. Br.-Bl., Frey, Jansen \& Moor 1936, given by their authors [14] in Catalonia, whereas the associations (46) Euphorbio terracinae-Anacycletum coronati Reyes, Wildpret \& León 2001 and (47) Bromo-Hirschfeldietum incanae Oberdorfer ex Lohmeyer 1975 have been given in Lanzarote by [31]; this last association was also given in Tenerife by [16], and is near the compact group of associations. Associations 19 and 47 given in Tenerife and Lanzarote presented a distance of $87.14 \%$, with very little similarity between them; both tables do not therefore correspond 
to the same association, and have major floristic and biogeographical differences. Table 19, with seven inventories given in Tenerife, is rich in Hordeumn leporinum Link and has four inventories without Hirschfeldia incana (L.) Lagr.-Foss.; there is no presence of Hordeum leporinum Link in the 47 given in Lanzarote which present as differentials from the previous Hordeum murinum L. subsp. glaucum (Steud.) Tzvelev, Erodium neuradifolium Delile, Avena fatua L. subsp. meridionales A. W. Hill, Avena sterilis L. subsp. ludoviciana (Durieu) Guillet \& Magne and the endemic species Sonchus bourgeaui Sch. Bip. In Webb \& Berthel (Figure 6 and Figure 7). W therefore propose a new association for Lanzarote: Soncho bourgeaui-Hirschfeldietum incanae Reyes et al. ex Cano nova, and we propose as type the synthetic inventory in Table 10 published by [31].

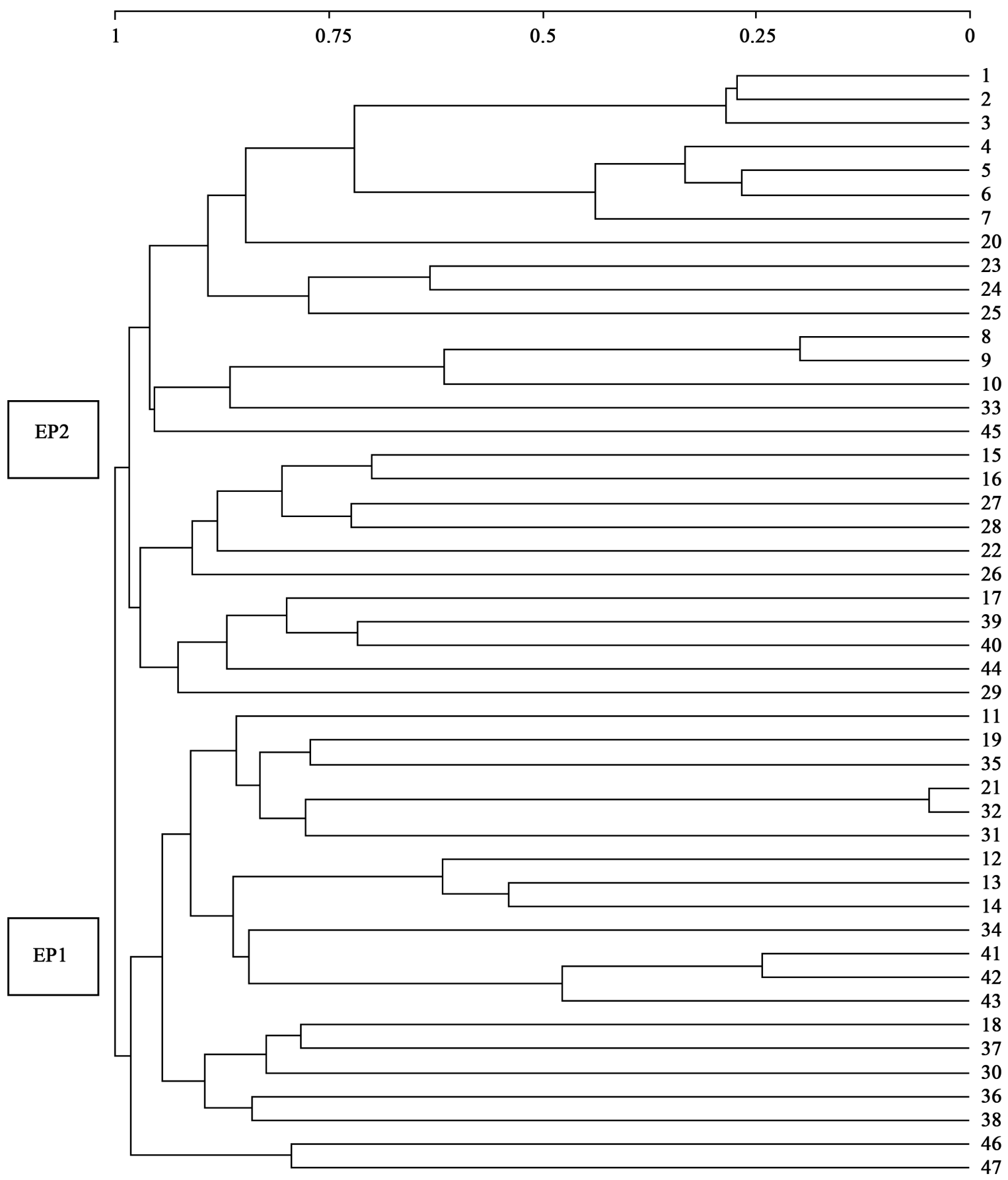

Figure 6. Jaccard distance clustering (Spain-N Morocco-Portugal). 


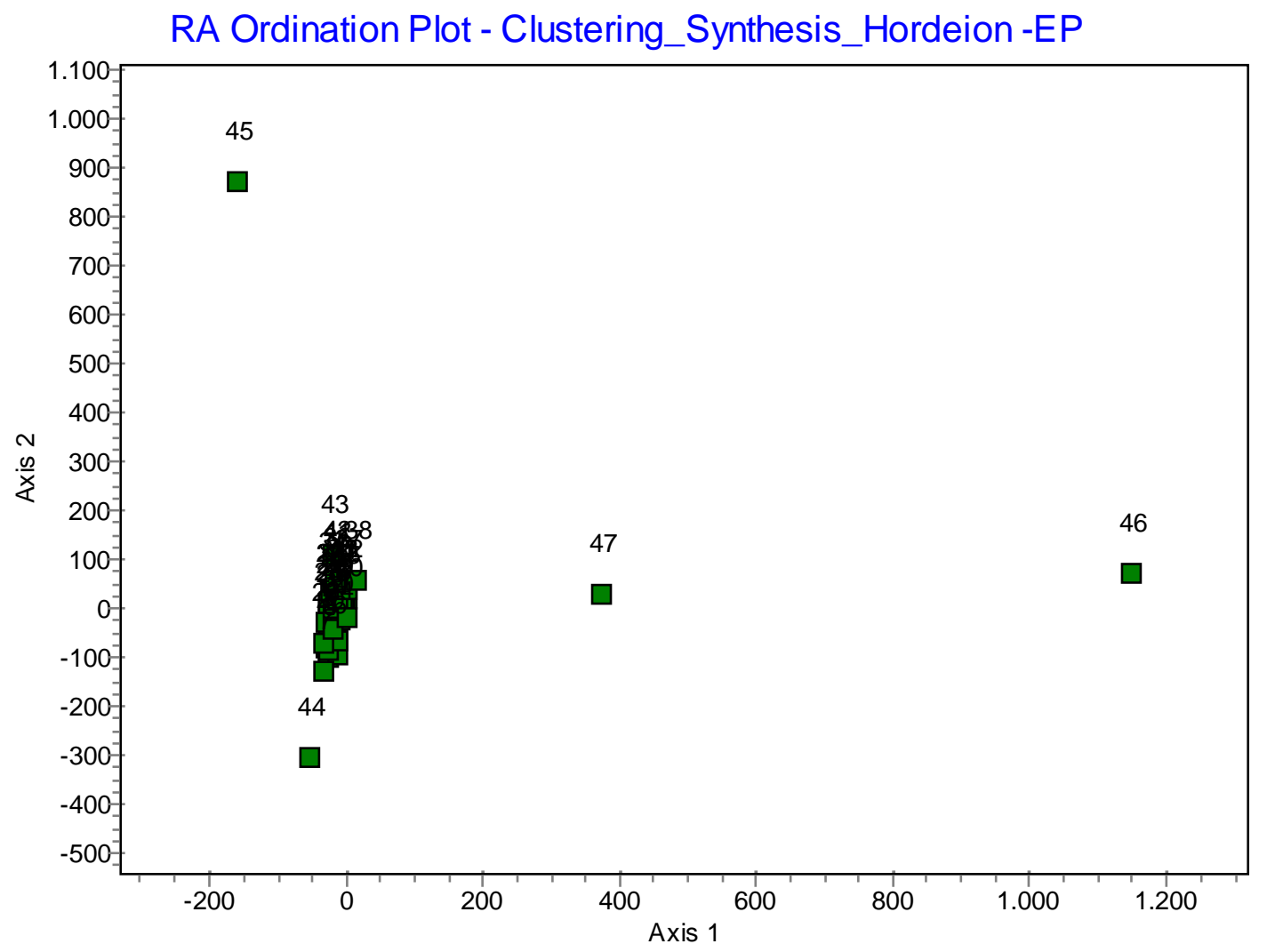

Figure 7. RA ordination analysis applied to the communities present in Spain, Portugal and northern Morocco.

In the case of Italy we applied the same statistical analysis as in the previous case. The cluster separates the tables of the associations belonging to the new alliance Securigero securidacae-Dasypyrion villosi, group M1 (association tables 48 - 74), from group M2 (51 - 63) (Figure 8) belonging to Hordeion leporini and to the new sub-alliance Resedo albae-Chrysanthemenion coronarii, with distances between both groups greater than $75 \%$. On applying the DECORANA ordination analysis, the two groups M1 and M2 are separated. Group M1 includes the association tables $48 \mathrm{AB}, 49 \mathrm{CA}, 50 \mathrm{SD}, 55 \mathrm{DA}, 70 \mathrm{BD}, 74 \mathrm{BD}, 71 \mathrm{VD}, 72 \mathrm{LD}, 73 \mathrm{AB}$ and $69 \mathrm{RP}$, but with a subgroup $\mathrm{M}_{1}$ formed by the communities inventoried by us (AB, CA, SD) (Figure 9).

The following cluster (Figure 10) based on the Excel chart with 281 rows (species) $\times 108$ columns (inventories), differentiates various groups. Group $\mathrm{G}_{1}(1 \mathrm{SD}-13 \mathrm{oLD})$ includes 16 of the 18 samples of the association Securigero securidacae-Dasypyretum villosii (1SD-16SD); the two remaining samples (2SD-3SD) are separated from the rest as they have a greater quantity of Hordeum leporinum Link than of Dasypyrum villosum (L.) Borba. Also belonging to group $\mathrm{G}_{1}$ are the inventories of the associations Vulpio ligusticae-Dasypyretum villosi (VD) and Laguro ovati-Dasypyretum villosi (LD), described by [36], which are together both in the cluster and in the DECORANA ordination analysis. The 11 inventories of Convolvulo elegantissimi-Aegilopetum geniculatae (CA) constitute a very clearly delimited group $\mathrm{G}_{2}$ (19CA-20CA). The following $20 \mathrm{G}_{3}$ samples (1oBDv-18oDBv) belong to the association Bromo rigidi-Dasypyretum villosi Pignatti 1953, described for the north-eastern plain of Venice (Italy). The association Aveno barbatae-Brometum diandri belongs to group $\mathrm{G}_{4}$ and comprises two subgroups: (30AB-43AB), which contains the 16 samples taken by us in grasslands in cultivated olive groves near Spoleto, Trevi, Foligno, Assisi (region of Umbria, Italy). The subgroup (10AB-12oAB) includes the original samples published by [39]. Finally, a separate group $\mathrm{G}_{5}(1 \mathrm{oDA}-4 \mathrm{oDA})$ contains the inventories corresponding to the association Dasypyro-Aegilopetum triuncialis described by [32] in the Aspromonte.

The DECORANA ordination analysis (Figure 11) gives a first group of inventories (A) which belong to the original associations $\mathrm{OAB}, \mathrm{oBDv}$ and the inventories taken by us belonging to $\mathrm{AB}$; and a second group (B) constituted by the associations VD and LD described by [36], [38], which are perfectly separated from the SD and CA communities included in group (C). 


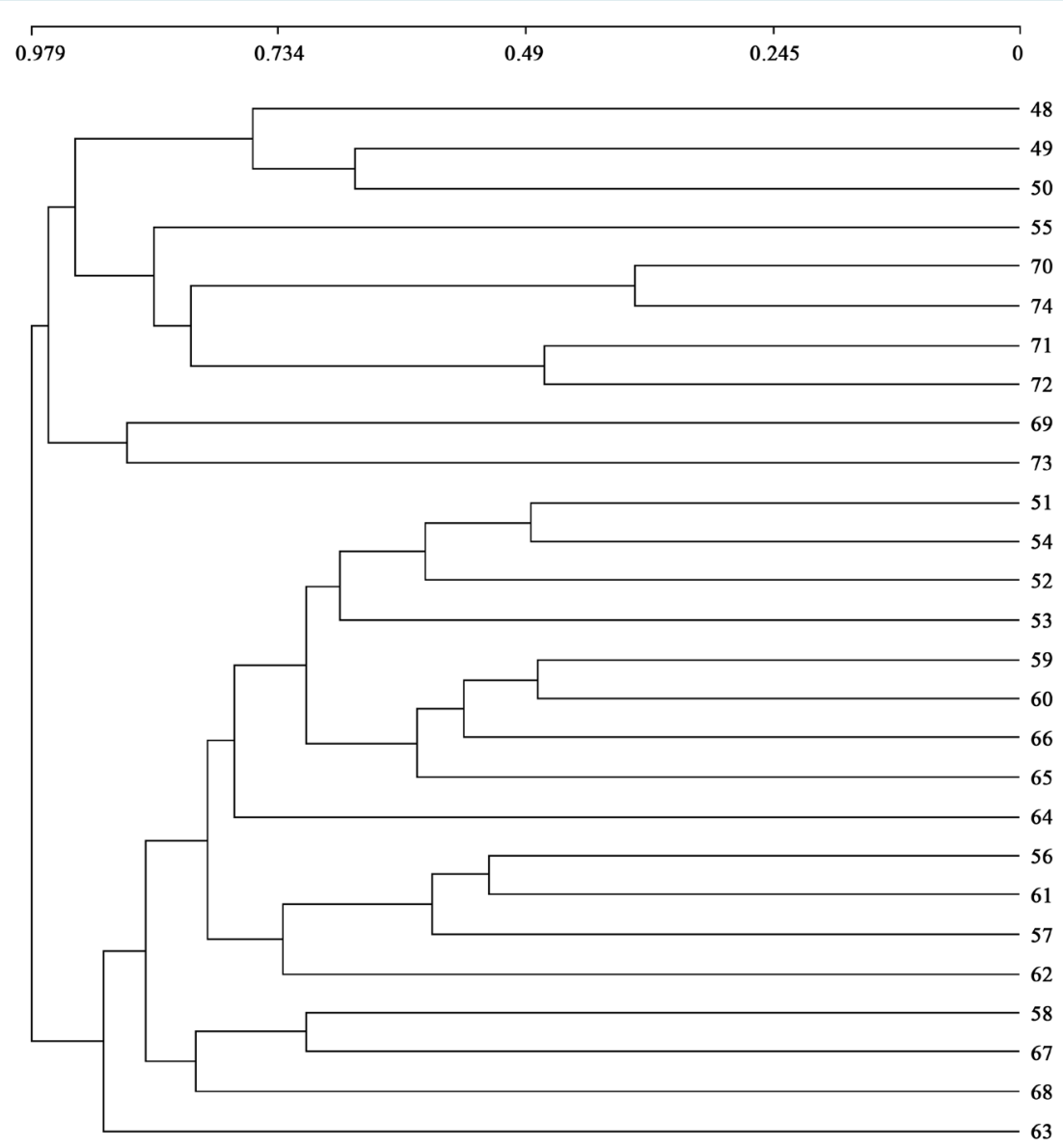

Figure 8. Jaccard distance clustering: Italian communities.

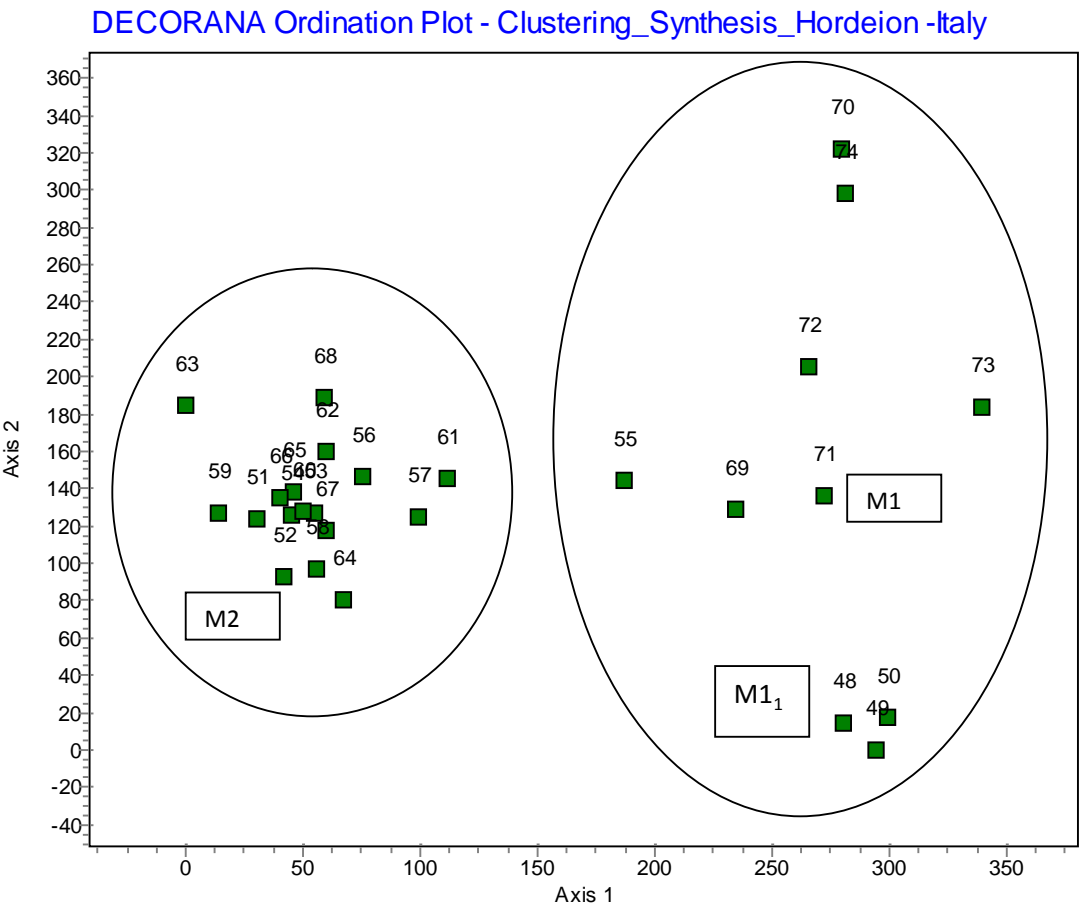

Figure 9. DECORANA ordination analysis: Italian communities. 


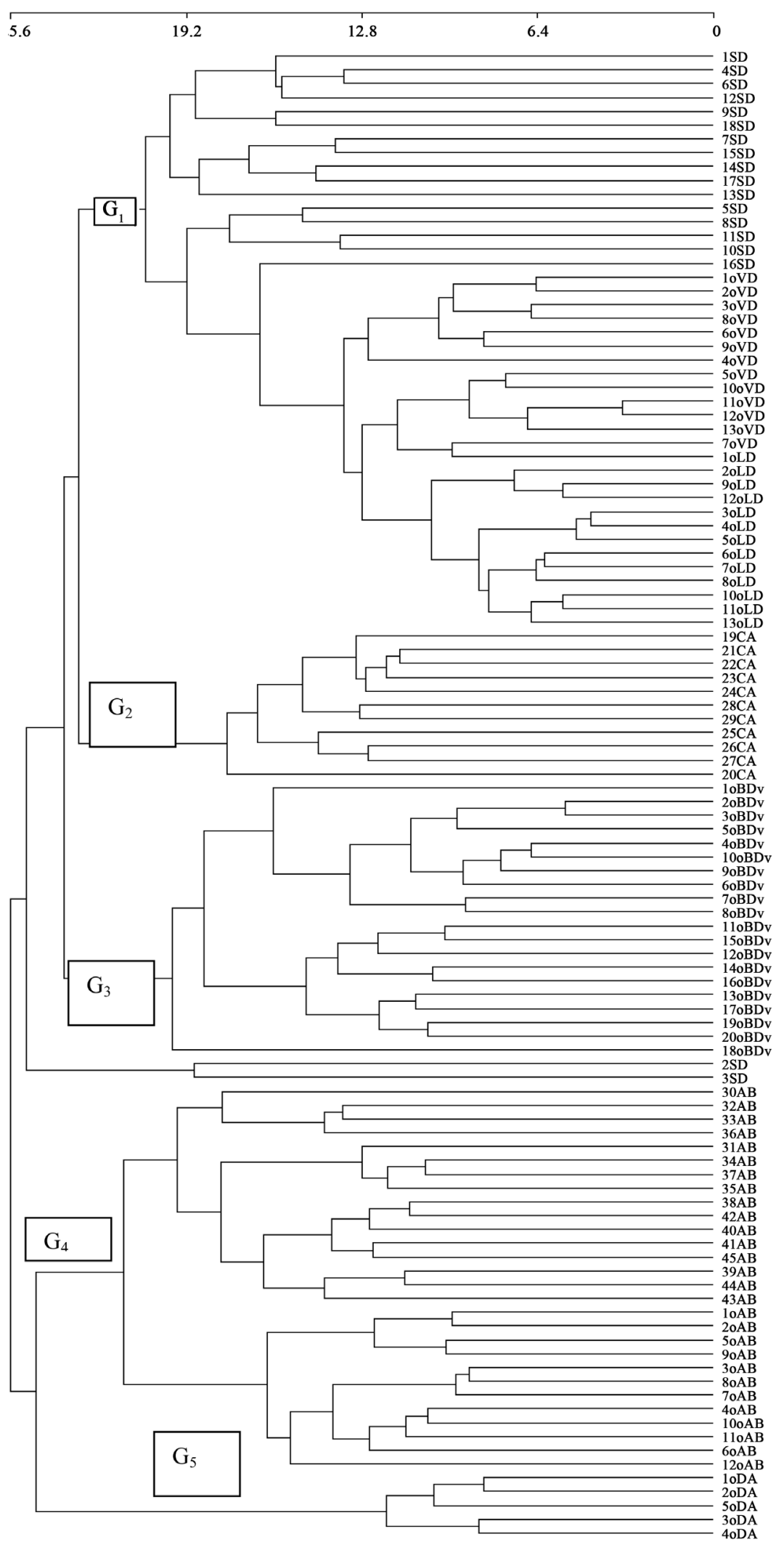

Figure 10. Euclidean distance cluster analysis for the Italian communities with Dasypyrm villosum. 


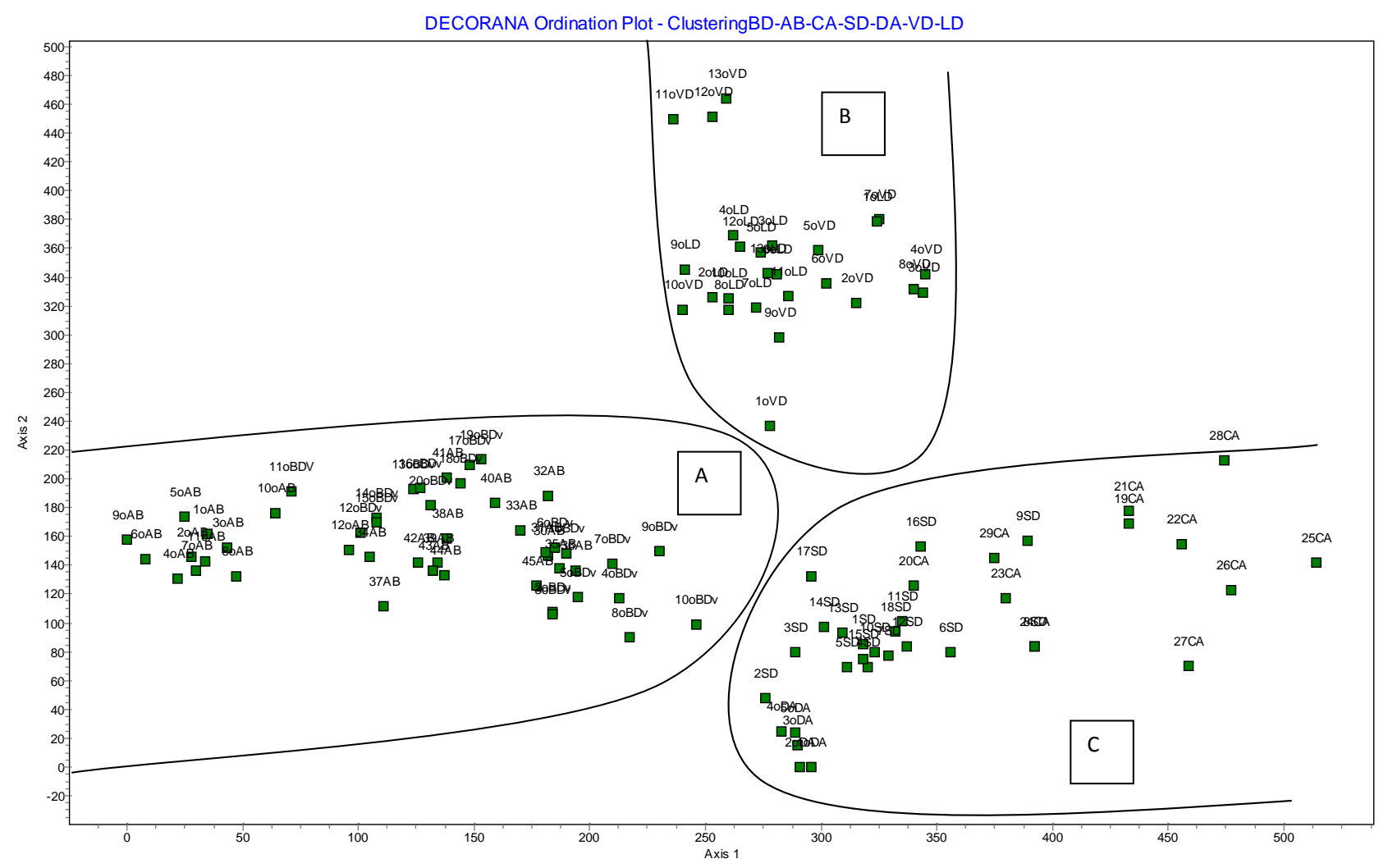

Figure 11. DECORANA ordination analysis for the Italian communities with Dasypyrm villosum.

The formation of two groups of Italian $\left(\mathrm{I}_{1}\right)$ and Iberian $\left(\mathrm{I}_{2}\right)$ communities (TT and PA) due to their soil differences, is corroborated by an analysis of conglomerates (Figure 12). The similarly between the CA communities in Italy and PA in Portugal and TT in Spain with regard to their physiognomy and plant structure does not justify their inclusion in the alliance Taeniathero-Aegilopion geniculatae; we thus maintain the CA communities within the new alliance Securigero securidacae-Dasypirion villosi.

As a result of the strong soil, floristic and biogeographical differences, we segregate from the alliance Hordeion leporini the communities rich in Dasypyrum villosum (L.) Borbas, which we include in the new alliance Securigero securidacae-Dasypirion villosi.

The alliance Hordeion leporini Br.-Bl. in Br.-Bl., Gajewski, Wraber et Walas 1936 corr. O. Bolòs 1962, includes grasslands growing in spring with a sub-nitrophilous and nitrophilous character. This alliance has its optimum in the Mediterranean and radiates to sub-Mediterranean territories. The species Dasypyrum villosum (L.) Borbas grows in the Gargano region in Italy, and is a calcicolous plant from southeast Europe which is absent from Spain and Portugal. A similar situation occurs with Securigera securidaca (L.) Deg. et Dorfl., which is distributed around southern Europe as far as southeast France. Crepis sancta (L.) Babc. appears frequently in the territories sampled in Italy, and is found in south-eastern Europe and the eastern Mediterranean region. This species is common in the region of La Marche, where it has been used to diagnose the vegetation infesting vineyards [40]. All the communities of Dasypyrum villosum (L.) Borbas are grassland formations with dense coverage and substantial biomass which flourish in environments with a high quantity of organic matter and nitrogen, with a pH always above 8 .

As a consequence of the considerable soil, floristic and biogeographical differences, we segregate from the alliance Hordeion leporine the communities rich in Dasypyrum villosum (L.) Borbas which we include in the new alliance Securigero securidacae-Dasypirion villosi. These are nitrophilous grasslands with a sub-Mediterranean, thermo, meso, supra-Mediterranean and Euro-Siberian (central-European) thermo, meso and sub-temperate character, whose characteristic species are Dasypyrum villosum (L.) Borbas, Securigera securidaca (L.) Deg. et Dorfl., Crepis sancta (L.) Babc. As type association we propose Bromo rigidi-Dasypiretum villosi Pignatti 1953. 


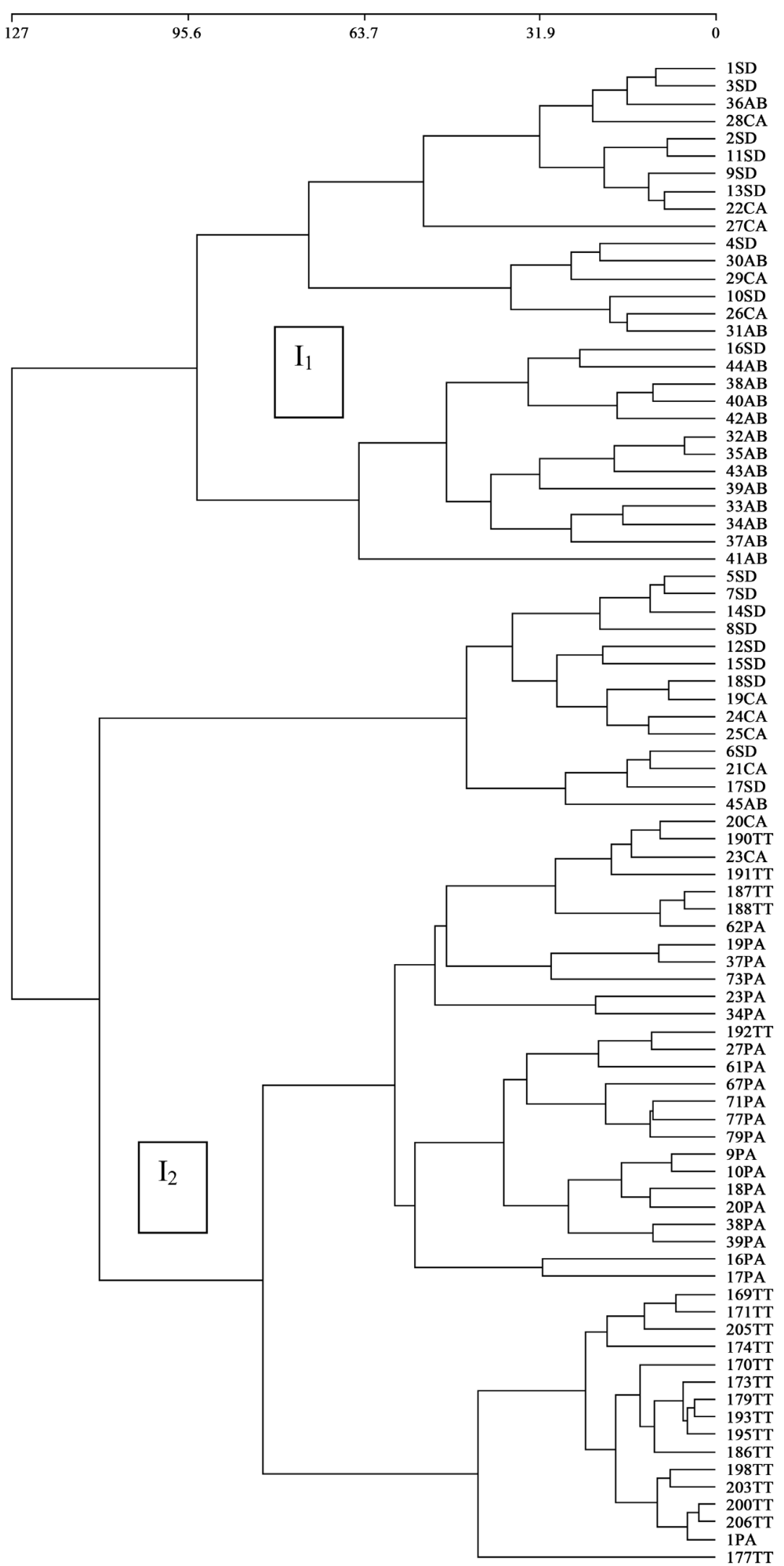

Figure 12. Cluster analysis among associations for Italy, Spain and Portugal. 
The three types of grasslands studied in Italy belong to three different communities AB, CA, SD, and are perfectly separated in the cluster and in the PCA (Figure 13 and Figure 14), with the exception of samples 2 and 3 in SD which are separated in the cluster but not in the PCA, due to their greater richness in alliance plants.

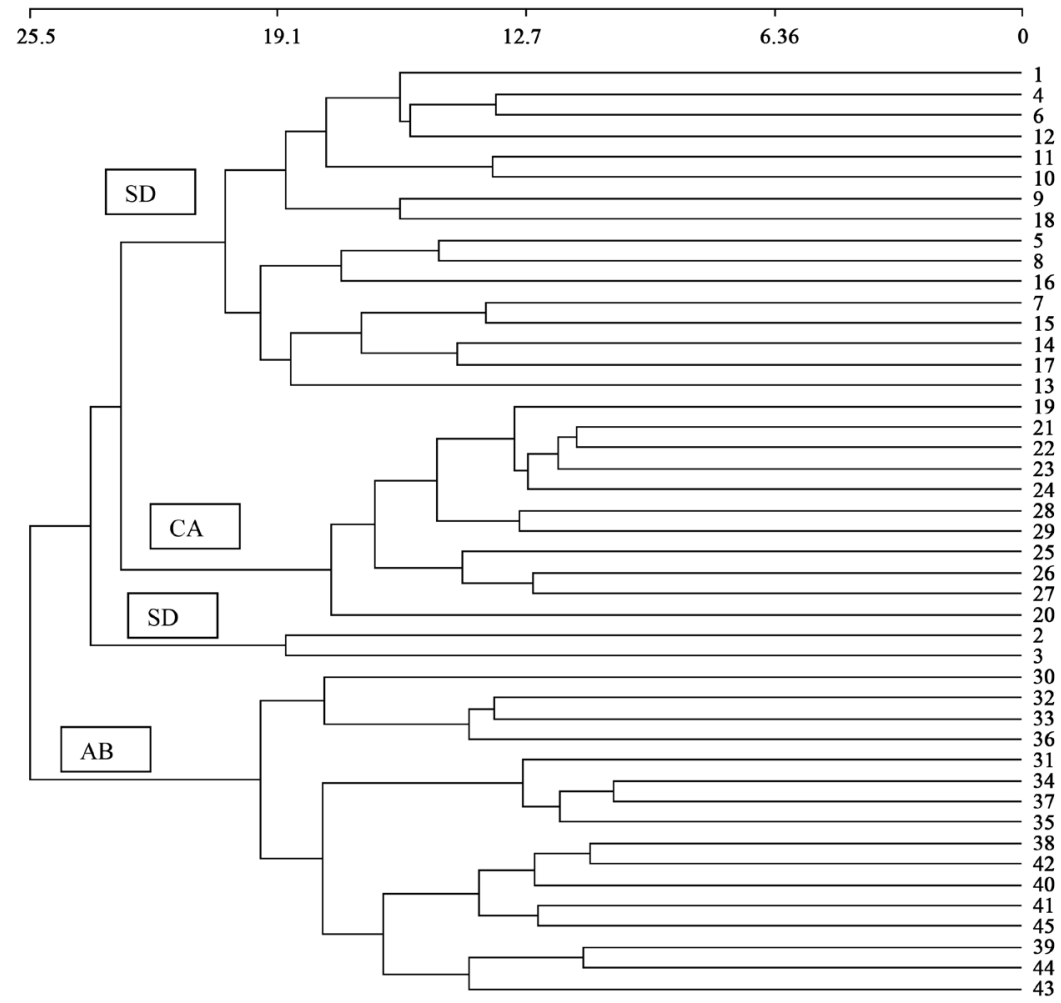

Figure 13. Cluster analysis for the three associations studied in Italy.

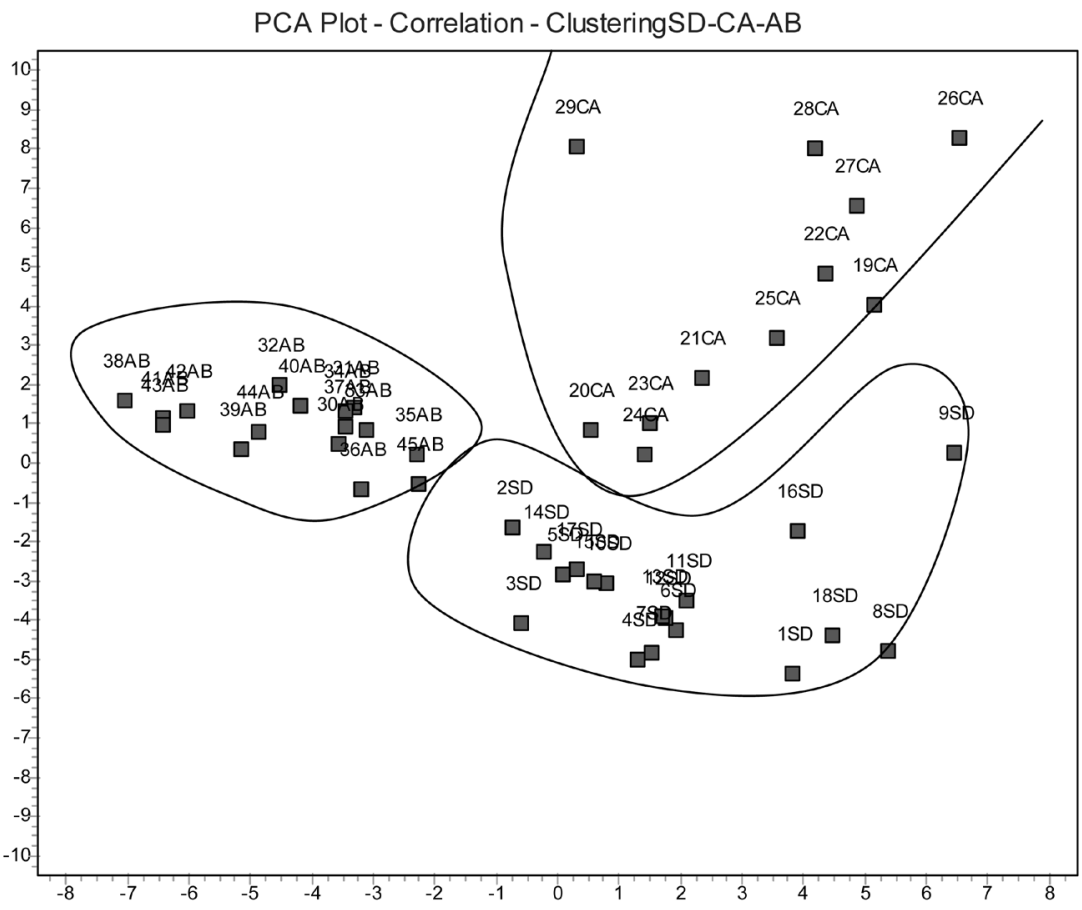

Figure 14. PCA for the three associations studied in Italy. 
Aveno barbatae-Brometum diandri Biondi \& Baldoni 1991 has been published by its authors for central Italy [39], initially located in the regions of Tuscany, Marche, Umbria and Lazio. The sampled community is a grassland with a ruderal character growing on disturbed soils, with therophytic vegetation whose successive evolution leads to perennial herbaceous formations of hemicryptophytes, belonging to the class Agropyretea intermediirepentis Muller et Görs 1969 and the alliance Convolvulo-Agropyrion repentis Görs 1967-a syntaxon which indicates good soil humidity-whereas in drier areas it contacts with the class Festuco-Brometea Br.-Bl. et Tx. 1943, association Centauro bracteatae-Brometum erecti Biondi et al. 1986. Its soil character indicates that it is located on terrains with $\mathrm{pH}$ values of 8.04; C.E.C (meq/100g) 24.685; OOM (\%) 6.389; P (p.p.m) 59.04; sandy-silty texture, average CR. This association is dominated by species such as Bromus Diandrus Roth, Bromus madritensis L., Avena barbata Pott ex Link, Hordeum leporinum Link.

The association Convolvulo elegantissimi-Aegilopetum geniculatae Cano-Ortiz, Biondi \& Cano nova hoc loco (Table 3 inv. 1-11 typus inv. 8) was inventoried by us in the region of Gargano, a territory located in southeast Italy on the coast of the Adriatic. Precipitation ranges between $686 \mathrm{~mm}$ and $1.082 \mathrm{~mm}$, and average annual $\mathrm{T}^{\mathrm{a}}$ is between $11.0^{\circ} \mathrm{C}-15.3^{\circ} \mathrm{C}$ [41]. The dominant materials are basic, with frequent appearance of decarbonated substrates with a neutral-basic character. The association we propose is characterised floristically by Aegilops geniculata Roth and the endemism Convolvulus elegantissimus Miller. This is a grassland which appears relatively frequently in abandoned olive groves, where the organic matter is somewhat inferior to the rest of the nearby communities (Table 2) such as Aveno barbatae-Brometum diandri Biondi et Baldoni 1991 and Securigero securidacae-Dasypyretum villosii; however the average annual $\mathrm{T}^{\mathrm{a}}$ is higher, and the thermotype is meso- and thermo-Mediterranean with a dry-subhumid ombrotype. The distribution area for this new syntaxon is at least the Gargano. Due to the soil values obtained, its floristic composition and its structure, we include this association Convolvulo elegantissimi-Aegilopetum geniculatae in the new alliance Securigero securidacae-Dasypyrion villosii. The new association is included in the series Cyclamidi hederifolii-Querco ilicis s., Cyclamidi hederifoliiQuerco Virginianae s., Fraxino orni-Querco ilicis s. [41].

Finally the association Seurigero securidacae-Dasypyretum villosii Cano-Ortiz, Biondi \& Cano nova hoc loco (Table 4 inv. 1-18 typus inv. 13); this community was inventoried in the region of Gargano, and grows in mesoMediterranean subhumid environments on basic substrates. It is dominated floristically by Dasypyrum villosum (L.) Borba, Securigera securidaca (L.) Deg. et Dorfl., Echium italicum L., Medicago tenoreana Ser., Medicago disciformis DC., Medicago intertexta (L.) Miller, Bromus ramosus Hudson.

This is a community which grows on soils with a higher content of MOO and nitrogen than Convolvulo elegantissimi-Aegilopetum geniculatae, and we include it in the alliance Securigero securidacae-Dasypyrion villosii. This new association Securigero securidacae-Dasypiretum villosii (50SD) is statistically separate from the Avenulo barbatae-Brometum diandri Biondi et Baldoni 1991 (48AB), (Figure 9) described for central Italy and which is characterised by Bromus diandrus Roth, Avena barbata Potter, Hordeum leporinum Link, Crepis vesicaria L. subsp. taraxacifolia [39]. It is additionally differentiated from the association Bromo rigidi-Dasypyretum villosi Pignatti 1953, also described for the eastern Venetian plain, which is characterised by a dominance of Dasypyrum villosum and Bromus rigidus (L.) Hubbard.

The high frequency of Securigera securidaca (L.) Deg. et Dorfl. in our association, absent in the previous associations, in addition to the bioclimatic and biogeographical differences, are sufficient reason to propose this new association with a sub-Mediterranean character and with a distribution areas which is at least the Gargano region.

\section{Conclusions}

This study clearly highlights the differentiation of Italian grasslands from Iberian grasslands, which are separated into two alliances: the alliance Hordeion leporini distributed throughout the western Mediterranean, from which we segregate the communities of Chrysanthemum coronarium L., as they present soil, floristic and structural differences which will be included in the new sub-alliance Resedo-Crhysanthemenion coronarii. The analysis of 74 association tables containing 847 inventories and the study of 16 soil parameters in each of the 265 samples provides sufficient information to propose the new alliance Securigero securidacae-Dasypyrion villosi, nitrophilous grasslands with a sub-Mediterranean, thermo, meso, supra-Mediterranean and Euro-Siberian (central-European) thermo, meso and sub-temperate character, whose characteristic species are Dasypyrum villosum (L.) Borba, Securigera securidaca (L.) Deg. et Dorfl., Crepis sancta (L.) Babc. As type association we 
Table 3. As. Convolvulo elegantissimi-Aegilopetum geniculatae Cano-Ortiz, Biondi \& Cano nova hoc loco.

\begin{tabular}{|c|c|c|c|c|c|c|c|c|c|c|c|c|}
\hline Order number & 1 & 2 & 3 & 4 & 5 & 6 & 7 & 8 & 9 & 10 & 11 & $\mathrm{P}$ \\
\hline Number of field inventory & 19 & 20 & 21 & 22 & 23 & 24 & 25 & 26 & 27 & 28 & 29 & $\mathrm{R}$ \\
\hline Slope \% & 0 & 0 & 0 & 0 & 0 & 0 & 7 & 5 & 0 & 0 & 0 & E \\
\hline Orientation & - & - & - & - & - & - & S & SE & - & - & - & S \\
\hline Coverage \% & 100 & 100 & 80 & 90 & 60 & 80 & 80 & 100 & 60 & 90 & 90 & E \\
\hline Área m² & 1 & 1 & 1 & 1 & 1 & 1 & 1 & 1 & 1 & 1 & 1 & $\mathrm{~N}$ \\
\hline Altitude in m & 49 & 68 & 44 & 33 & 31 & 21 & 38 & 255 & 98 & 186 & 312 & $\mathrm{C}$ \\
\hline Average height of dominant vegetation in $\mathrm{m}$ & 0.300 & 0.400 & 0.300 & 0.250 & 0.250 & 0.250 & 0.300 & 0.250 & 0.200 & 0.250 & 0.250 & E \\
\hline Average height of dominant vegetation in $\mathrm{m}$ & 0.400 & 0.500 & 0.400 & 0.350 & 0.300 & 0.350 & 0.400 & 0.350 & 0.250 & 0.350 & 0.350 & S \\
\hline \multicolumn{13}{|l|}{ Association characteristics and higher units } \\
\hline Aegilops geniculata Roth & 5 & 5 & 4 & 4 & 3 & 4 & 4 & 5 & 3 & 4 & 4 & V \\
\hline Dasypyrum villosum (L.) Borbas & 1 & 2 & + & 1 & + & 1 & & + & & + & 1 & IV \\
\hline Avena fatua $\mathrm{L}$. & + & + & & + & + & 1 & & + & 1 & & & III \\
\hline Scorpiurus muricatus L. & + & 1 & 1 & 1 & & + & 1 & & & & & III \\
\hline Plantago lagopus L. & 2 & & 1 & + & + & & & 1 & & & 1 & III \\
\hline Medicago disciformis DC. & & 3 & & 1 & 1 & & + & 2 & 1 & & & III \\
\hline Leontodon taraxacoides (Vill.) Merat & & & & + & & 1 & + & + & + & + & & III \\
\hline Trifolium campestre Schreber & 1 & 3 & & & + & 1 & & + & & & & II \\
\hline Satureja cuneifolia Ten. & & & & 1 & & & + & + & + & + & & II \\
\hline Anagallis coerulea Schreber & & + & & & + & & + & 1 & + & & & II \\
\hline Urospermum picroides (L.) Schmidt & & & + & & + & & & & + & + & & II \\
\hline Urospermum dalechampii (L.) Schmidt & & & + & + & & & & & & + & + & II \\
\hline Scabiosa maritima L. & 1 & & & + & & & & + & & + & & II \\
\hline Reichardia picroides (L.) Roth & + & & + & + & & & + & & & & & II \\
\hline Ononis ornithopodioides L. & + & & & + & & & & + & + & & & II \\
\hline Medicago arabica (L.) Hudson & + & & & + & 1 & & & & & & 1 & II \\
\hline Euphorbia peplus L. & + & & & & & + & & + & & & 1 & II \\
\hline Convolvulus elegantissimus Miller & & & & + & & & 1 & 1 & & + & & II \\
\hline Bromus ramosus Hudson & & + & + & & + & 1 & & & & & & II \\
\hline Stipa capensis Thunb. & & & & & & & & & + & 1 & 1 & I \\
\hline Onobrychis aequidentata (S. et S.) D’Urv. & & & & & & & 3 & + & 1 & & & I \\
\hline Muscari comosum (L.) Miller & + & & & & & & & + & & + & & I \\
\hline Linum strictum L. & & & & & & & & & 1 & 1 & + & I \\
\hline Hordeum leporinum Link & & 2 & & & & + & & & & & + & I \\
\hline Galactites tomentosa Moench & + & & + & & & + & & & & & & I \\
\hline Trifolium stellatum L. & & & & & & & & 1 & + & & & I \\
\hline Tordylium apulum L. & & & & & & & & & + & & + & I \\
\hline Securigera securidaca (L.) Deg. et Dorfl. & + & & 1 & & & & & & & & & I \\
\hline Picris hieracioides L. & & & & & + & 1 & & & & & & I \\
\hline
\end{tabular}




\section{Continued}

Onobrychis caput-galli (L.) Lam.

22

Lotus ornithopodioides L.

Lotus creticus L.

Linum bienne Miller

Cynosurus echinatus L.

Catapodium rigidum (L.) Hubbard

Briza maxima L.

Vicia lutea L.

Vicia bithynica (L.) L.

Trifolium scabrum L.

Trifolium resupinatum L.

Trifolium dubium Sibth.

Trifolium bocconei Savi

Trifolium arvense $\mathrm{L}$.

Torilis nodosa (L.) Gaertner

Sonchus asper (L.) Hill

Silene conica L.

Sherardia arvensis L.

Scandix pecten-veneris L.

Reseda alba L.

Plantago afra L.

Ononis reclinata $\mathrm{L}$.

Mercurialis ambigua L. fil.

Medicago orbicularis (L.) Bartal.

Medicago murex Willd.

Lolium temulentum L.

Lathyrus ochrus (L.) DC.

Lagurus ovatus L.

Hedysarum coronarium L.

Hedypnois cretica (L.) Willd.

Galium lucidum All.

Euphorbia exigua L.

Daucus carota L.

Crepis vesicaria $\mathrm{L}$.

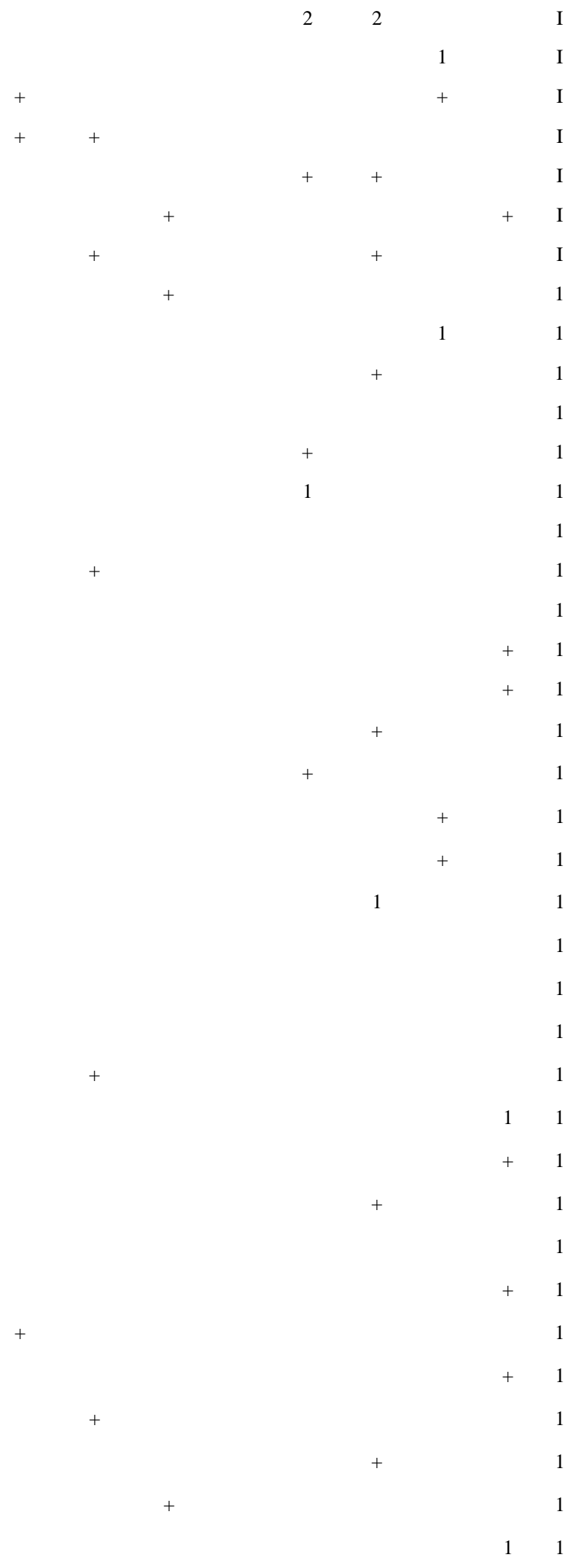




\section{Continued}

Centaurium erythraea Rafn

Centaurea deusta Ten.

Biscutella didyma $\mathrm{L}$.

Bellardia trixago (L.) All.

Anthyllis tetraphylla $\mathrm{L}$.

Anthemis tinctoria L.

Companion species

Dactylis glomerata L.

Tragopogon porrifolius ssp. australis sensu Richarson

Sanguisorba minor Scop.

Psoralea bituminosa L.

Polygala monspeliaca L.

Pallenis spinosa (L.) Cass.

Serapias parviflora Parl.

Hippocrepis unisiliquosa $\mathrm{L}$.

Cynodon dactylon (L.) Pers.

Brachypodium distachyum (L.) Beauv.

Allium roseum L.

Trifolium subterraneum L.

1 Serapias vomeracea (Burm.) Briq.

Poa bulbosa L.

Plantago serraria L.

1

Hypericum perforatum L.

Helianthemum salicifolium (L.) Miller

Gladiolus italicus Miller

Crupina crupinastrum (Moris) Vis.

Cirsium arvense (L.) Scop.

Cerastium glomeratum Thuill.

Cephalaria leucantha (L.) Schrader \& Schult

Carduus pycnocephalus L.

Astragalus sesameus L.

Anthyllis vulneraria L.

Allium subhirsutum L.

Sites: All the inventories were taken in the region of Apulia (Gargano), Italy.

\begin{tabular}{cccccccccccc}
$\begin{array}{c}\text { Number } \\
\text { inventory }\end{array}$ & 1 & 2 & 3 & 4 & 5 & 6 & 7 & 8 & 9 & 10 & 11 \\
\hline $\begin{array}{c}\text { Coordinata } \\
\mathbf{X}(\mathbf{m})\end{array}$ & $2,604,242$ & $2,612,533$ & $2,613,213$ & $2,613,482$ & $2,614,885$ & $2,615,399$ & $2,618,141$ & $2,617,148$ & $2,614,802$ & $2,610,874$ & $2,606,277$ \\
$\begin{array}{c}\text { Coordinata } \\
\mathbf{Y}(\mathbf{m})\end{array}$ & $4,641,580$ & $4,638,281$ & $4,637,520$ & $4,637,494$ & $4,637,275$ & $4,637,323$ & $4,632,400$ & $4,627,869$ & $4,622,944$ & $4,619,398$ & $4,616,095$ \\
\hline
\end{tabular}


Table 4. As. Securigero securidacae-Dasypyretum villosii Cano-Ortiz, Biondi \& Cano nova hoc loco.

\begin{tabular}{|c|c|c|c|c|c|c|c|c|c|c|c|c|c|c|c|c|c|c|c|}
\hline Order number & 1 & 2 & 3 & 4 & 5 & 6 & 7 & 8 & 9 & 10 & 11 & 12 & 13 & 14 & 15 & 16 & 17 & 18 & $\mathrm{P}$ \\
\hline Number of field inventory & 1 & 2 & 3 & 4 & 5 & 6 & 12 & 11 & 7 & 8 & 9 & 10 & 15 & 13 & 14 & 16 & 17 & 18 & $\mathrm{R}$ \\
\hline Slope \% & 4 & 3 & 2 & 0 & 0 & 0 & 0 & 3 & 8 & 9 & 10 & 2 & 2 & 3 & 0 & 0 & 0 & 0 & $\mathrm{E}$ \\
\hline Orientation & $\mathrm{SE}$ & SE & $\mathrm{NE}$ & - & - & - & - & $\mathrm{N}$ & NE & SE & SW & $\mathrm{NE}$ & SE & $\mathrm{N}$ & - & SW & - & - & S \\
\hline Coverage \% & 100 & 90 & 100 & 100 & 100 & 100 & 100 & 60 & 90 & 100 & 70 & 70 & 100 & 100 & 100 & 90 & 70 & 90 & $\mathrm{E}$ \\
\hline Área m² & 2 & 2 & 2 & 2 & 2 & 2 & 2 & 2 & 2 & 2 & 2 & 2 & 2 & 2 & 2 & 2 & 2 & 2 & $\mathrm{~N}$ \\
\hline Altitude in m & 324 & 289 & 258 & 182 & 110 & 72 & 130 & 169 & 117 & 227 & 317 & 194 & 286 & 141 & 269 & 245 & 92 & 52 & $\mathrm{C}$ \\
\hline Average height of dominant vegetation in $\mathrm{m}$ & 0.8 & 0.4 & 0.6 & 0.6 & 0.8 & 0.6 & 0.6 & 0.35 & 0.9 & 0.7 & 0.35 & 0.45 & 0.45 & 0.5 & 0.45 & 0.5 & 0.5 & 0.8 & $\mathrm{E}$ \\
\hline Average height of dominant vegetation in $\mathrm{m}$ & 0.8 & 0.6 & 0.5 & 0.9 & 1 & 1 & 1 & 0.8 & 0.5 & 1.2 & 0.5 & 0.7 & 0.9 & 1 & 0.8 & 1 & 1 & 0.9 & $\mathrm{~S}$ \\
\hline \multicolumn{20}{|l|}{ Association characteristics and higher units } \\
\hline Dasypyrum villosum (L.) Borbas & 4 & & 2 & 5 & 5 & 5 & 5 & 3 & 4 & 5 & 3 & 3 & 5 & 5 & 5 & 4 & 3 & 4 & $\mathrm{~V}$ \\
\hline Securigera securidaca (L.) Deg. et Dorfl. & + & 1 & & 1 & 2 & 2 & + & 1 & 1 & 2 & 1 & & 2 & + & & 1 & 1 & & IV \\
\hline Leontodon taraxacoides (Vill.) Merat & 2 & 1 & 2 & 2 & & 2 & & 2 & + & 2 & 1 & 2 & + & 1 & & & & & III \\
\hline Bromus ramosus Hudson & 5 & 1 & 2 & 3 & & 2 & 5 & & & & 1 & 1 & + & & 1 & & 1 & 2 & III \\
\hline Briza maxima L. & 1 & + & & + & & 1 & 1 & 1 & 1 & 1 & 1 & & & 1 & & & & 1 & III \\
\hline Sherardia arvensis L. & 1 & & & & 2 & & 1 & 1 & 1 & & + & 1 & 1 & & & & + & 1 & III \\
\hline Avena fatua $\mathrm{L}$. & 2 & & 1 & & 1 & + & + & & & 2 & & & + & & & + & + & + & III \\
\hline Vicia lutea $\mathrm{L}$. & + & + & & + & + & + & 1 & & & & & & 2 & 1 & & & + & & III \\
\hline Nigella damascena L. & & & & & & + & + & + & 1 & 1 & & & + & 1 & & 1 & 1 & & III \\
\hline Sonchus asper (L.) Hill & + & + & & + & & & & + & & & & & & 1 & & + & & + & II \\
\hline Medicago intertexta (L.) Miller & & & 2 & 1 & & + & + & & 1 & & & & 2 & & 2 & & & & II \\
\hline Erodium malacoides (L.) L’HÚr. & 1 & 2 & 2 & 1 & & + & & & & & & & & & 1 & & + & & II \\
\hline Anagallis coerulea Schreber & + & + & & 1 & & + & & & + & & + & & & & & & + & & II \\
\hline Urospermum picroides (L.) Schmidt & & & + & & & & & + & + & & & & 1 & 1 & + & & & & II \\
\hline Trifolium stellatum L. & & & + & + & & & & & & & 3 & 2 & 2 & & & & & 2 & II \\
\hline Medicago orbicularis (L.) Bartal. & & 2 & 1 & 1 & & & & & 2 & & & & 2 & & & & 1 & & II \\
\hline Lotus ornithopodioides L. & & 1 & & + & & & & + & & & & & & & + & 1 & + & & II \\
\hline Galactites tomentosa Moench & & & & & & & + & 2 & + & & & 2 & & 1 & & & & + & II \\
\hline Hordeum leporinum Link & & 3 & 5 & & & & & & & & & & & 3 & 2 & & 2 & & I \\
\hline Geranium molle L. & & 2 & & 1 & & & & & & & & + & & + & & + & & & I \\
\hline Euphorbia peplus L. & & & & 1 & & & & & + & & & & & & + & + & + & & I \\
\hline Vicia bithynica (L.) L. & & & & & 1 & + & 1 & & & & & & & & & & + & & I \\
\hline Reichardia picroides (L.) Roth & + & & & & & & & & & & + & & & & & + & & 1 & I \\
\hline Picris hieracioides L. & + & & & & & & 1 & & & & & & & & & 1 & + & & I \\
\hline Medicago sativa $\mathrm{L}$. & + & 3 & 2 & 2 & & & & & & & & & & & & & & & I \\
\hline Medicago murex Willd. & & & 2 & & + & & & & & & & 1 & & & & & & 1 & I \\
\hline Convolvulus arvensis L. & & & & + & & & + & + & & & & & + & & & & & & I \\
\hline Bunias erucago L. & & & 1 & & & & + & & & & & & & & 1 & & 2 & & I \\
\hline Borago officinalis L. & & & & & + & & & & + & & & & & & + & & + & & I \\
\hline
\end{tabular}




\section{Continued}

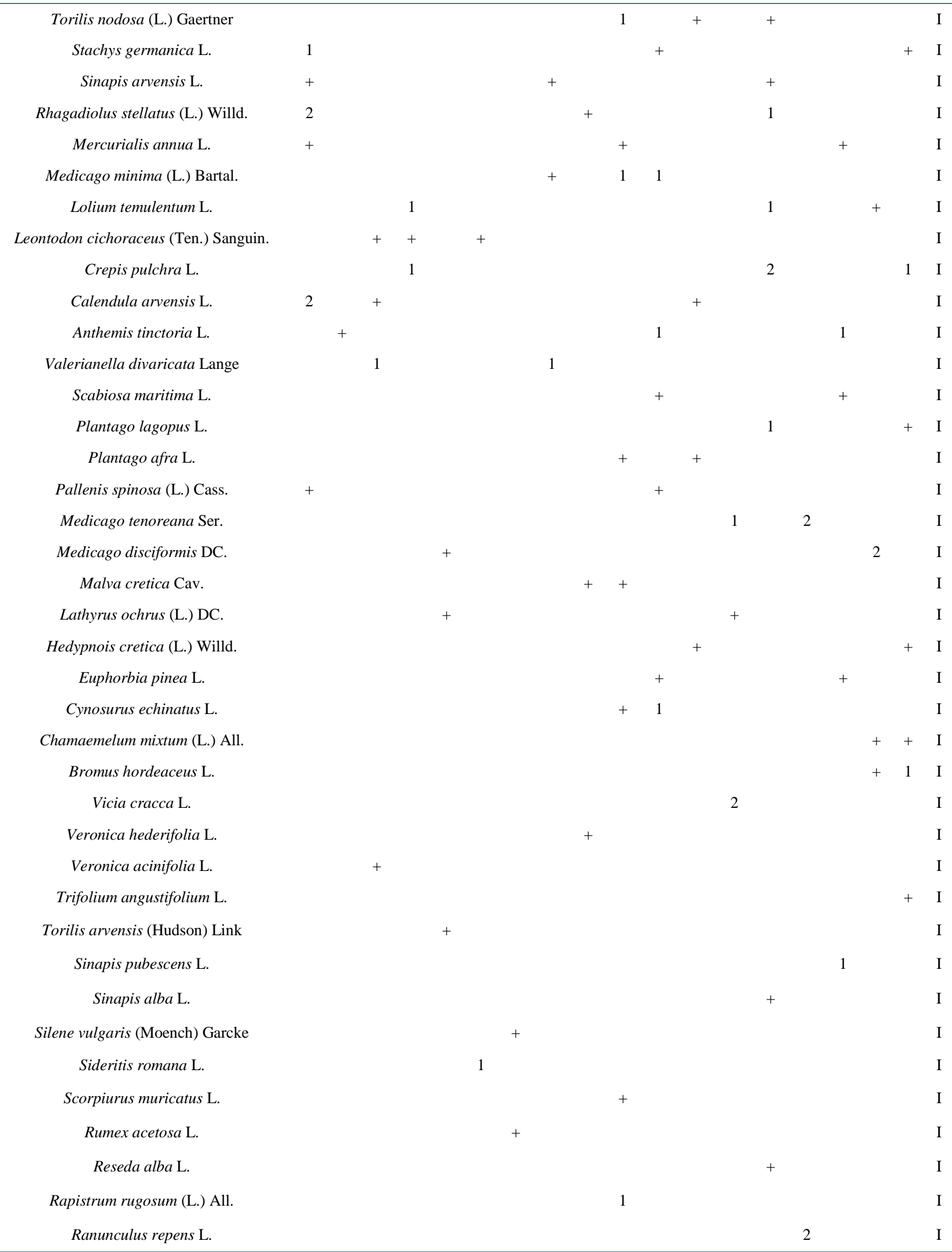




\section{Continued}

Ornithogalum umbellatum L.

Orlaya kochii Heyw.

1

Ononis ornithopodioides L.

Medicago truncatula Gaertner

Medicago rugosa Desr.

Medicago rigidula (L.) All.

Medicago lupulina L.

Medicago arabica (L.) Hudson

Lotus corniculatus L.

Lolium rigidum Gaudin

Linaria vulgaris Miller

Lathyrus sphaericus Retz.

Lathyrus annuus L.

Lagurus ovatus L.

Geranium lucidum L.

Euphorbia helioscopia L.

Euphorbia exigua L.

Echium vulgare L.

Echium italicum L.

Daucus carota L.

Cynoglossum creticum Miller

Crepis vesicaria L. ssp. vesicaria

Coronilla scorpioides (L.) Koch

Cirsium arvense (L.) Scop.

Cichorium intybus L.

Chrysanthemum segetum L.

Cerinthe major L.

Centaurium erythraea Rafn

Bellardia trixago (L.) All.

Anthyllis tetraphylla L.

Aegilops geniculata Roth

\section{Companion species}

Carduus pycnocephalus L.

Tordylium apulum L.

Theligonum cynocrambe L.

Arum italicum Miller

Rubus ulmifolius Schott

Geranium dissectum L.

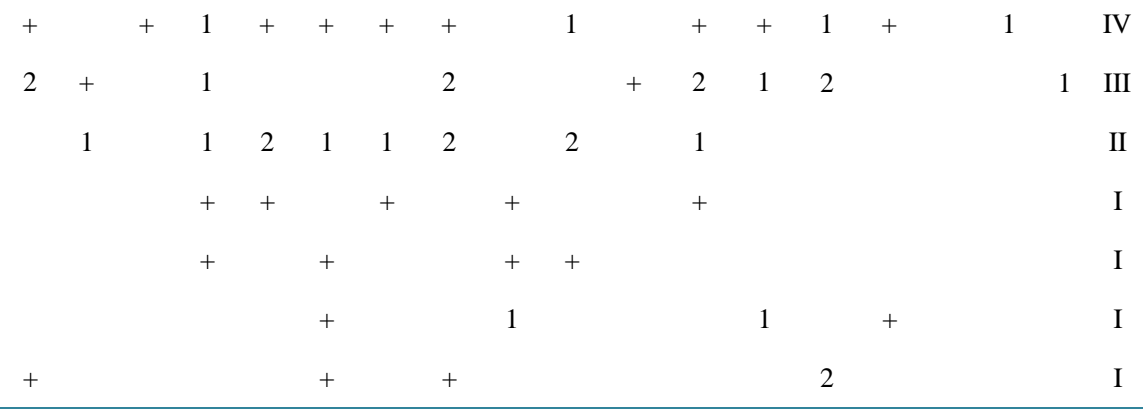




\section{Continued}

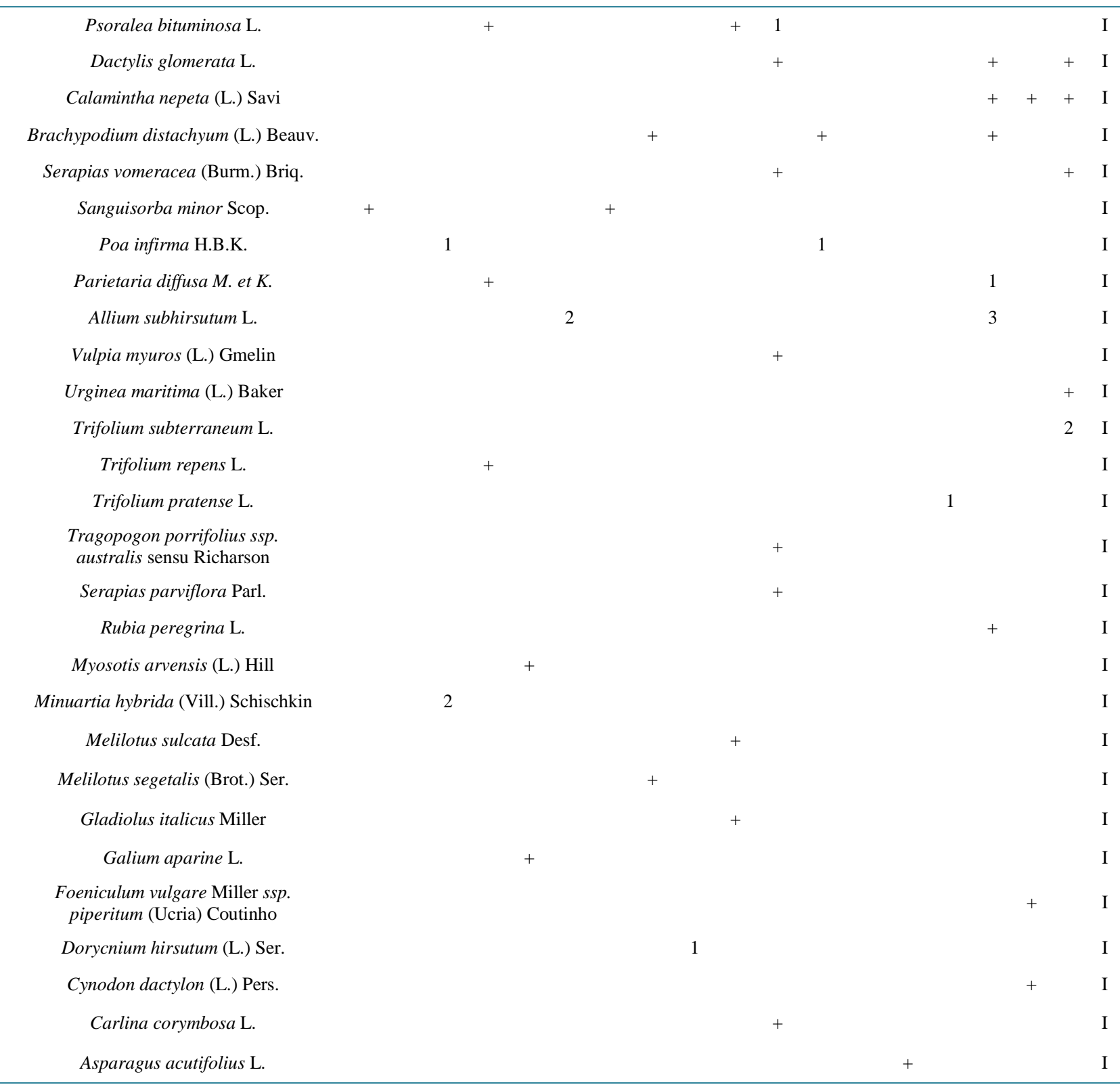

Sites: All the inventories were taken in the region of Apulia (Gargano), Italy.

\begin{tabular}{|c|c|c|c|c|c|c|c|c|c|c|c|c|c|c|c|c|c|c|}
\hline $\begin{array}{l}\text { Number } \\
\text { inventory }\end{array}$ & 1 & 2 & 3 & 4 & 5 & 6 & 7 & 8 & 9 & 10 & 11 & 12 & 13 & 14 & 15 & 16 & 17 & 18 \\
\hline 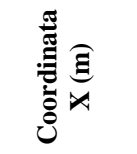 & $\begin{array}{l}n \\
\hat{0} \\
\delta \\
0 \\
0 \\
i\end{array}$ & $\begin{array}{l}9 \\
\infty \\
8 \\
8 \\
6 \\
i\end{array}$ & $\begin{array}{l}\infty \\
\sigma \\
\delta \\
\delta \\
0 \\
i\end{array}$ & 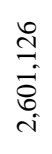 & 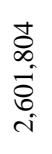 & 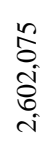 & 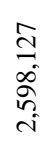 & $\begin{array}{l}\text { Nิ } \\
\text { ô } \\
0 \\
0 \\
\text { N }\end{array}$ & 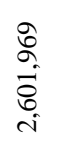 & $\begin{array}{l}\stackrel{8}{2} \\
\text { ì } \\
\dot{0} \\
\text { i }\end{array}$ & $\begin{array}{l}\hat{\omega} \\
0 \\
\infty \\
0 \\
0 \\
i\end{array}$ & $\begin{array}{l}\text { N̂} \\
\text { ô } \\
\text { On } \\
\text { N }\end{array}$ & 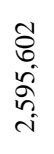 & 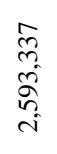 & 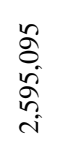 & 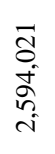 & 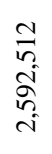 & 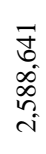 \\
\hline 氶 & 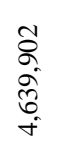 & $\begin{array}{l}0 \\
8 \\
0 \\
0 \\
6 \\
+\end{array}$ & $\begin{array}{l}0 \\
0 \\
m \\
0 \\
\dot{f} \\
0 \\
\dot{f}\end{array}$ & $\begin{array}{l}\overrightarrow{\tilde{V}} \\
\vec{\nabla} \\
\dot{\sigma} \\
\dot{+}\end{array}$ & 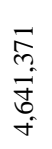 & 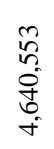 & 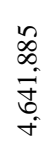 & 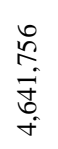 & 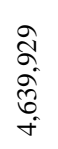 & 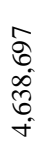 & 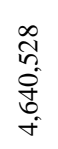 & 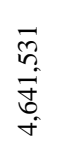 & 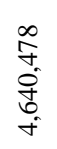 & 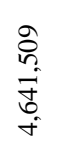 & $\begin{array}{l}\hat{0} \\
\vec{b} \\
0 \\
\dot{G} \\
\dot{f}\end{array}$ & $\begin{array}{l}\vec{G} \\
\text { के } \\
\dot{\theta} \\
\dot{+}\end{array}$ & $\begin{array}{l}\stackrel{9}{y} \\
\text { oे } \\
\text { రु } \\
\dot{\forall}\end{array}$ & $\begin{array}{l}0 \\
0 \\
\infty \\
0 \\
0 \\
0 \\
\forall\end{array}$ \\
\hline
\end{tabular}


propose Bromo rigidi-Dasypyretum villosi Pignatti 1953. In this alliance we include all the associations rich in Dasypyrum villosum (L.) Borbas and the two new associations inventoried by us: Convolvulo elegantissimi-Aegilopetum geniculatae and Securigero securidacae-Dasypyretum villosii. We propose the new sub-alliance Resedo albae-Chrysanthemenion coronarii subordinated to the alliance Malvion neglectae, in which we include all the associations rich in Chrysanthemum coronarium L. In order to arrive at these conclusions, it was necessary to take into consideration the value of soil factors as the cause of the abundance of the species, and to establish the values for the different soil parameters which act as soil nutrients for the different grassland communities. We therefore used the synthetic Braun-Blanquet index, adapting it for the first time to the Van der Maarel values; this gives considerable strength to the presence of the species in the community, making it possible to establish the distance between associations. We also propose the new association Soncho bourgeaui-Hirschfeldietum incanae Reyes et al. ex Cano nova, based on the table of [31].

\section{References}

[1] Brullo, S. (1983) L'Hordeion leporini in Sicilia. Archivio Botanico e Biogeografico Italiano, 58, 55-88.

[2] Rivas-Martínez, S. (1978) La vegetación de Hordeion leporini en España. Doc. Phytosoc, 9, 377-392.

[3] Vargas, M.A.A. (1996) Flora y vegetación del valle de Villena (Alicante). Inst. Cultura Juan Gil-Albert. Dip. Porv. Alicante, $261 \mathrm{p}$.

[4] Biondi, E., Bagella, S., Cassavechia, S., Pinzi, M. and Vagge, I. (1999) La vegetazione a Dasypyrum villosum (L.) P. Candargy lungo le coste dell'Italia Settentrionale. Documents Phytosociologiques, 19, 439-446.

[5] Cano-Ortiz, A. (2007) Bioindicadores ecológicos y manejo de cubiertas vegetales como herramienta para la implantación de una agricultura sostenible. Tesis doctoral, Universidad de Jaén, Jaén, 708 p.

[6] Cano-Ortiz, A., Pinto-Gomes, C.J., Esteban Ruiz, F.J., Torres, A.R., Goñi, J., De la Haza, I. and Cano, E. (2009) Biodiversity of Hordeion leporini in Portugal: A phytosociological and edaphic análisis. Acta Botanica Gallica: Botany Letters, 156, 33-48. http://dx.doi.org/10.1080/12538078.2009.10516140

[7] Cano-Ortiz, A., Pinto-Gomes, C.J., Ruiz, F.J.E. and Cano, E. (2009) Determination of the Nutritional State of Soils by Means of the Phytosociological Method and Different Statistical Techniques (Bayesian Statistics and Decision Trees) in Spain. Acta Botanica Gallica: Botany Letters, 156, 607-624. http://dx.doi.org/10.1080/12538078.2009.10516180

[8] Cano-Ortiz, A., Pinto-Gomes, C.J. and Cano, E. (2010) Contribution to the Study of the Taenithero-Aegilopion geniculatae Alliance in Portugal. Acta Botanica Gallica: Botany Letters, 157, 599-610. http://dx.doi.org/10.1080/12538078.2010.10516234

[9] Cano-Ortiz, A., Del Río González, S. and Gomes, C.J.P. (2013) Impact of Soil Texture on Plant Communities. Plant Sociology, 50, 39-46.

[10] Costa, C., Capelo, J., Jardin, R., Sequeira, M., Espirito-Santo, D., Lousa, M., Fontinha, S., Aguiar, C. and Rivas-Martínez, S. (2004) Catálogo sintaxonómico e florístico das comunidades vegetais da Madeira e Porto Santo. Quercetea, 6, 61-200.

[11] Pignatti, S. (1982) Flora d’Italie. Edagricole, Bologna.

[12] Tutin, et al. (1964-1993) Flora Europea. Vol. I-V, Cambridge University Press, Cambridge.

[13] Braun-Blanquet, J. (1979) Fitosociología. Bases para el estudio de las comunidades vegetales. Ed. Blume. Madrid.

[14] Braun-Blanquet, J., Quer, P.F., Braun-Blanquet, G., Frey, E., Jansen, P. and Moor, M. (1936) L'excursion de la sigma en Catalogne (Pâgues 1934). Cavanillesia, 7, 153-167.

[15] Goday, S.R. (1964) Vegetación y florula de la cuenca extremeña del Guadiana. Excma. Dip. Prov. Badajoz, Madrid, $777 \mathrm{p}$

[16] Rivas-Martínez, S., Wildpret, W., Del Arco, M., Rodríguez, O., de Paz, P.P.L., García-Gallo, A., Acebes, J.R., Díaz González, T.E. and Fernández-González, F. (1993) Comunidades vegetales de la Isla de Tenerife (Islas Canarias). Itinera Geobotánica, 7, 69-374.

[17] Roscales, S.S. (2004) Flora y vegetación del macizo occidental de la Sierra de Gredos (Sistema Central, España). Guineana, 10, 1-474.

[18] Fuentes, A.G., Cano, E., Torres, J.A. and Nieto, J. (1994) Notas sobre la vegetación nitrófila de la cuenca del Guadalquivir. Naturalia Baetica, 6, 125-153.

[19] Peinado, M., Martínez-Parras, J.M. and Bartolomé, C. (1986) Notas sobre vegetación nitrófila II: Algunas novedades fitosociológicas en Andalucía. Studia Botanica, 5, 53-69.

[20] Orellana, J.A.V. and de Mera, A.G. (2008) Nuevas aportaciones al conocimiento de la vegetación luso-extremadurense. 
Estudio de las sierras de las Villuercas (Extremadura, España) y San Mamede (Alto Alentejo, Portugal). Acta Botanica Malacitana, 33, 169-214.

[21] Maestre, M.A.V. (1997) La sierra de Crevillente: Flora y vegetación. Inst. Cultura Juan Gil-Albert. Dip. Porv. Alicante, $320 \mathrm{p}$.

[22] Rivas-Martínez, S., Costa, M. and Loidi, J. (1992) La vegetación de las islas de Ibiza y Formentera (Islas Baleares, España). Itinera Geobotánica, 6, 99-236.

[23] Fuentes, A.G. and Cano, E. (1993) Aportación al conocimiento de los herbazales nitrófilos hispalenses. Boletín del Instituto de Estudios Giennenses, 148, 275-287.

[24] Neto, C.S. (2002) A Flora e a Vegetaçao do superdistrito sadense (Portugal). Guineana, 8, 1-269.

[25] Pereira, M.M.D. (2009) A Flora e Vegetaçao da Serra de Monfurado (Alto Alentejo-Portugal). Guineana, 15, 1-316.

[26] Bolòs, O., Molinier, R. and Montserrat, P. (1970) Observations phytosociologiques dans l'ile de Minorque. Acta Botanica Barcinon, 5, 1-150.

[27] Chueca, F.E. (1972) Vegetación y flora de las regiones central y meridional de la provincia de Murcia. Murcia, 451 p

[28] Magallon, A.R. (1972) Flora y vegetación de la provincia de Alicante. Inst. Est. Alicantinos. Alicante, 403 p.

[29] de Mera, A.G., Deil, U. and Orellana, J.A.V. (2004) Roadside vegetation in the campo de Gibraltar (sw Spain) and on the Tanger Península (nw Maorocco). Studia Botanica, 23, 63-93.

[30] Prieto, P., Espinosa, P. and Fábregas, S.F. (1973) Ecología y flora de los tejados de Granada. Trabajos del Departamento de Botánica. Universidad de Granada, 2, 97-102.

[31] Betancort, J.A.R., De La Torre, W.W. and León, M.C. (2001) The Vegetation of Lanzarote (Canary Islands). Phytocoenologia, 31, 185-247. http://dx.doi.org/10.1127/phyto/31/2001/185

[32] Brullo, S., Scelsi, F. and Spampinato, G. (2001) La vegetazione dell’ Aspromonte Studio Fitosociologico. Ed. Laruffa. Reggio Calabria.

[33] Ferro, G. (1980) La vegetazione di Butera (Sicilia meridionale). Attidell'Istituto Botanico e Laboratorio Crittogamico Università di Pavia, 13, 51-118.

[34] Ferro, G. (2004) Nuovi dati sulla flora e sulla vegetazione dei coltivici e degli incolti di Lipari (Isole Eolie). Quaderni di BotanicaAmbientale e Applicata, 15, 21-39.

[35] Kruska, K. (1985) Contributo alla conoscenza della vegetazione ruderale delle Marche. Documents Phytosociologiques, 9, 359-368.

[36] Falleni, G. (1998) Dasypyrum villosum Vegetation in Territory of Rome. Rendiconti Lincei, 9, 149-170. http://dx.doi.org/10.1007/BF02904397

[37] Biondi, E., Vagge, I., Baldoni, M. and Taffetani, F. (1997) La vegetazione del Parco fluviale del Taro (Emilia-Romagna). Fitosociologia, 34, 69-110.

[38] Falleni, G. and Lucchese, F. (1998) The Status of Brometalia rubenti-Tectorum Communities from the Mediterranean Area in Different Syntanomical Schemes. Rendiconti Lincei, 9, 241-255. http://dx.doi.org/10.1007/BF02904407

[39] Biondi, E. and Baldoni, M. (1991) La vegetazione di margine stradale dell'ordine Brometalia rubenti-tectori nell’Italia Centrale. Annalidi Botanica, 49, 214-217.

[40] Baldoni, M., Biondi, E. and Loiotile, A (2001) La vegetazione infestante i vigneti nelle Marche. Fitosociologia, 38, 6368.

[41] Falleni, G., Lucchese, F. and Paura, B. (2001) La praterie a Stipa austroitalica du sue settori adriatici meridionali (Molise e Gargano). Fitosociologia, 38, 25-36.

[42] van der Maarel, E. (1979) Transformation of Cover-Abundance Values in Phytosociology and Its Effects on Community Similarity. Vegetatio, 39, 97-114. http://dx.doi.org/10.1007/BF00052021

[43] Gutte, P. (1966) Die Verbreitung einiger Ruderalpflanzengesellschaften in der witeren Umgebung von Leipzig. Wiss.Z. Martin-Luther-Univ. Halle-Wittemberg. Math.-Naturwiss. Reihe 15:937-1010. 


\section{Syntaxonomical Checklist}

Stellarietea mediae Tüxen, Lohmeyer \& Preising ex von Rochow 1951

Chenopodio-Stellarienea Rivas Goday 1956

Sisimbrietalia officinalis J. Tüxen in Lohmeyer \& al. 1962 em. Rivas-Martínez, Báscones, T. E. Díaz, Fernández-González \& Loidi 1991

Hordeion leporini Br.-Bl. in Br.-Bl., Gajewski, Wraber \& Walas 1936 corr. O. Bolòs 1962

Bromo scoparii-Hordeetum leporinii Rivas-Martínez 1978

Papaveri rhoeadi-Diplotaxietum virgatae Rivas-Martínez 1978

Anacyclo radiati-Hordeetum leporini O. Bolòs \& Rivas-Martínez in Rivas-Martínez 1978

Anacyclo radiati-Papaveretum rhoeadis Cano-Ortiz, Pinto-Gomes, Esteban, Rodríguez-Torres, Goñi, De la Haza \& Cano 2009

Anacyclo clavati-Hordeetum leporinii Cano-Ortiz, Pinto-Gomes, Esteban \& Cano 2009

Carduo tenuiflori-Hordeetum leporini Br.-Bl. 1931

Bromo-Hirschfeldietum incanae Lohmeyer 1975

Iondrabo auriculatae-Erucetum vesicariae Rivas-Martínez 1978

Rapistro rugosi-Sisymbrietum crassifolii Rivas-Martínez 1978

Hordeo leporini-Glossoppapetum macroti Peinado, Martínez-Parras \& Bartolomé 1986

Co. Linaria spartea et Raphanus raphanistrum

Raphano raphanistri-Diplotaxietum catholicae Vicente Orellana \& Galán 2008

Asphodelo fistulosi-Hordeetum leporini A. \& O. Bolòs in O. Bolòs 1956

Aveno lusitanicae-Hordeetum leporini Espirito Santo, J. C. Costa, Jardin \& Sequeira 2004

Bromo madritensis-Galactitetum tomentosae O. Bolòs, Molinier \& P. Monserrat 1970

Eruco longirostris-Diplotaxietum erucoidis Rigual 1972 corr. Alcaraz 1984

Sisymbrio irionis-Sinapietum mairei P. Prieto, Espinosa \& S. Fernández 1973 corr. Rivas-Martínez et al. 2002

Schismo calycini-Malvetum trifidae Br.-Bl., Font Quer, G. Br.-Bl., Frey, Jansen \& Moor 1936

Euphorbio terracinae-Anacycletum coronati Reyes, Wildpret \& León 2001

Soncho bourgeaui-Hirschfeldietum incanae Reyes ex Cano nova hoc loco

Hordeo-Sisymbrietum orientalis Oberd. 1954

Hordeo-Crepidetum bursifoliae Brullo, Scelsi \& Spanpinato 2001

Centaureetum napifoliae Brullo 1983

Hypochoerido-Plantaginetum serrariae Brullo 1983

Hordeo-Senecionetum squalidi Brullo 1983

Hordeo-Erodietum acaulis Brullo 1983

Hordeo-Vulpietum ligusticae Brullo 1983

Carduetum australis Brullo 1983

Senecioni cosyrensi-Hordeetum leporini Brullo 1983

Hordeo-Centauretum macracanthae Brullo 1983

Malvion neglectae (Gutte 1966) status novo

Resedo albae-Chrysanthemenion coronarii Cano-Ortiz, Biondi \& Cano suball. nova

Resedo albae-Chrysanthemetum coronarii O. Bolòs \& Molinier 1958

Anacyclo radiati-Chrysanthemetum coronarii (Rivas-Martínez 1978) Cano-Ortiz, Pinto-Gomes, Esteban, Rodríguez-Torres, Goñi, De la Haza \& Cano 2009

Malvo parviflorae-Chrysanthemetum coronarii Ferro 1980

Lavatero creticae-Chrysanthemetum coronarii Ferro 2004

Securigero securidacae-Dasypyrion villosi Cano-Ortiz, Biondi \& Cano all. nova

Bromo rigidi-Dasypyretum villosi Pignati 1953

Securigero securidacae-Dasypyretum villosi Cano-Ortiz, Biondi \& Cano nova hoc loco

Convolvulo elegantissimae-Aegilopetum geniculatae Cano-Ortiz, Biondi \& Cano nova hoc loco

Aveno barbatae-Brometum diandri Baldoni \& Biondi 1993

Dasypyro-Aegilopetum triuncialis Brullo, Scelsi \& Spanpinato 2001

Laguro ovati-Dasypyretum villosi Falleni 1998

Vulpio ligusticae-Dasypyretum villosi Falleni 1998 
Rumici-Carduetum pycnocephali Kruska 1985

Artemisietea vulgaris Lohmeyer, Preising \& Tüxen ex von Rochow 1951

Carthametalia lanati Brullo in Brullo \& Marcenò 1985

Silybo-Urticion Sissingh ex Br.-Bl. \& O. Bolòs 1958

Chrysanthemo-Silybetum mariani Bullo 1983 
Scientific Research Publishing (SCIRP) is one of the largest Open Access journal publishers. It is currently publishing more than 200 open access, online, peer-reviewed journals covering a wide range of academic disciplines. SCIRP serves the worldwide academic communities and contributes to the progress and application of science with its publication.

Other selected journals from SCIRP are listed as below. Submit your manuscript to us via either submit@scirp.org or Online Submission Portal.
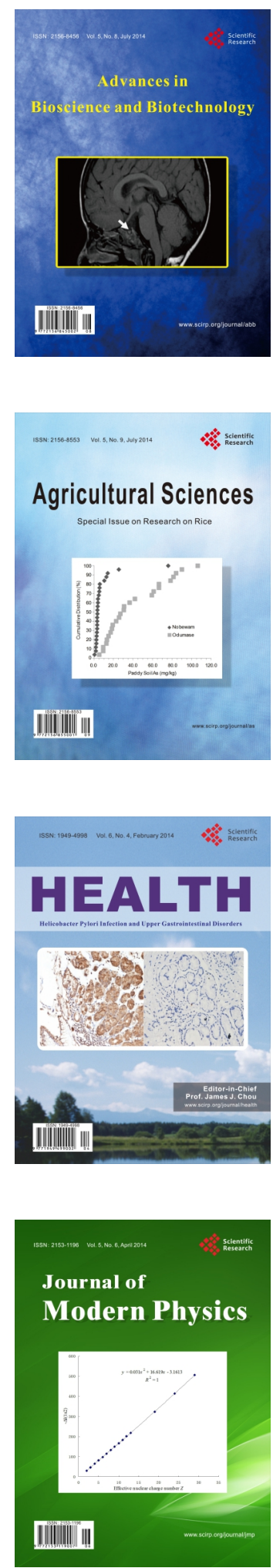
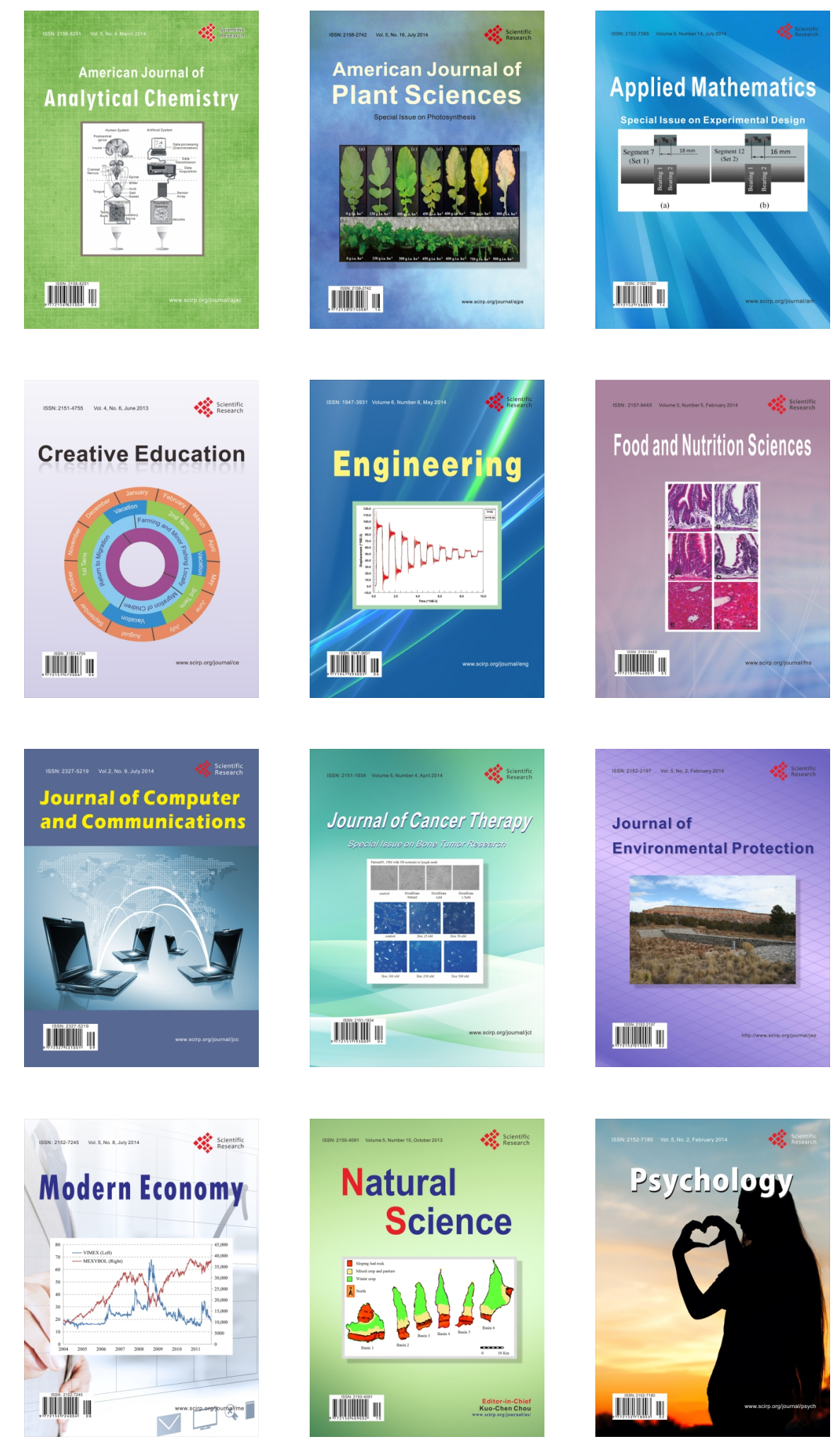